\title{
Micro-framework reconstruction from peloidal-dominated mud mounds (Viséan, SW Spain)
}

\author{
Marta Rodríguez-Martínez • Joachim Reitner • \\ Ramón Mas
}

Received: 29 July 2008 / Accepted: 16 January 2009 / Published online: 22 September 2009

(C) Springer-Verlag 2009

\begin{abstract}
Currently, the different roles of peloidal micrites are not well understood in matrix-supported bioconstructions such as mud mounds. Upper Viséan outcrops from Guadiato Valley, Cordoba Province, SW Spain provide well-preserved peloidal-dominated mud mounds. Microstructual analysis of these mud mounds has allowed us to establish 13 microfabrics. Although peloids are conspicuous constituents in the microfabrics, they have been differentiated into seven peloidal-dominated types, grouped into three categories: (a) homogeneous fine peloidal types (3 subtypes); (b) homogeneous coarse peloidal types ( 2 subtypes); and (c) heterogeneous coarse peloidal types (two subtypes). Fast $\mathrm{cm}$-scale microfabric changes were mapped directly onto thin sections. This methodology allows the researcher to recognize the micro-framework of these mud mounds as a complex, multiepisodic organization of microframes and intermicroframes that are formed by primary and secondary automicrites (non-reworked and reworked automicrites, respectively), autochthonous internal sediment, and allomicrite and marine fibrous cements.
\end{abstract}

\footnotetext{
M. Rodríguez-Martínez ( $\square$ )

Departamento de Geología, Universidad de Alcalá,

Ctr. Madrid-Barcelona, km 33.6, 28871 Alcalá de Henares,

Madrid, Spain

e-mail: marta.rodriguezm@uah.es

J. Reitner

Department of Geobiology, Geowissenchftliches

Zentrum der Universität Göttingen, Goldschmidtstr. 3,

37077 Göttingen, Germany

e-mail: jreitne@dwdg.de

R. Mas

Departamento de Estratigrafía,

Universidad Complutense de Madrid, 28040 Madrid, Spain

e-mail: ramonmas@geo.ucm.es
}

The thin-section mapping was also used to estimate the automicrite-allomicrite relationship, which is crucial in separating the microbial and biodetrital mud mounds.

Keywords Mud mound · Peloids · Automicrites · Micro-framework $\cdot$ Carboniferous $\cdot$ Spain

\section{Introduction}

Mississippian bioconstructions have a wide compositional spectrum as well as broad tectonostratigraphic distributions and varied temporal patterns (Webb 1994, 2002; Bridges et al. 1995; Somerville 2003; Aretz and Chevallier 2007). Their study and classification system have been mainly focused on skeletal and non-skeletal components, cavity system development, and diagenetic features (Lees and Miller 1995; Ahr and Stanton 1996; Jeffery and Stanton 1996; Madi et al. 1996).

Bioconstruction is used here in a global sense to include the whole reef-mud mound spectrum. In this report, we take a broad, non-genetic, non-morphological, and descriptive definition of mud mound at the macroscopic scale, as a bioconstruction composed of more than $50 \%$ of rock volume by fine-grained 'carbonate matrix' that can be texturally and genetically varied (automicrites and allomicrites occur). In volume terms, mud mounds can be considered matrix-supported bioconstructions. Genetically, however, their carbonate matrix can represent a volume ranging from 10 to $100 \%$ of recognizable biologically induced framework, or, on the contrary, it can represent an allochthonous carbonate matrix externally produced and later deposited. Despite the current body of knowledge, some questions still remain. How much volume percentage is necessary in order to consider them 'microbial mounds' or 'biodetrital mounds'? 
How is it possible to recognize their internal organization or accretional mechanisms?

The isolated Mississippian outcrops from Guadiato Valley (Córdoba, Spain) are composed mainly of siliciclastic deposits of a narrow foreland basin sensu lato developed during the Variscan continental collision between the Ossa Morena and the Central Iberian terrains (Fig. 1a). In this tectonic context, the mud mound factory was very important and well developed in narrow and tectonically controlled blocks. In fact, the Upper Viséan strata provide abundant and excellent examples of mud mounds (Rodríguez-Martínez 2005; Rodríguez-Martínez et al. 2003). Their macrofabric is massive, cryptalgal or leiolitic, but, microscopically, they comprise complex microfabrics, most of them peloidal-rich ones.

In regards to the study of mud mounds, general related questions are (1) the origin and/or source of carbonate mud, (2) the existence or lack of internal organization, and (3) the ability of the produced carbonate mud to form rigid, synsedimentary accretional structures. This study is focused on the last two questions.

Since the 1980s, mud mounds have been seen as selfsufficient carbonate factories where the autochthonous production of carbonate mud occurs. In Mississippian mud mounds, the 'multi-component mudstone' of Lees (1964) and the later 'polymuds' fabrics (Lees and Miller 1985) are

\section{A Iberian Massif}

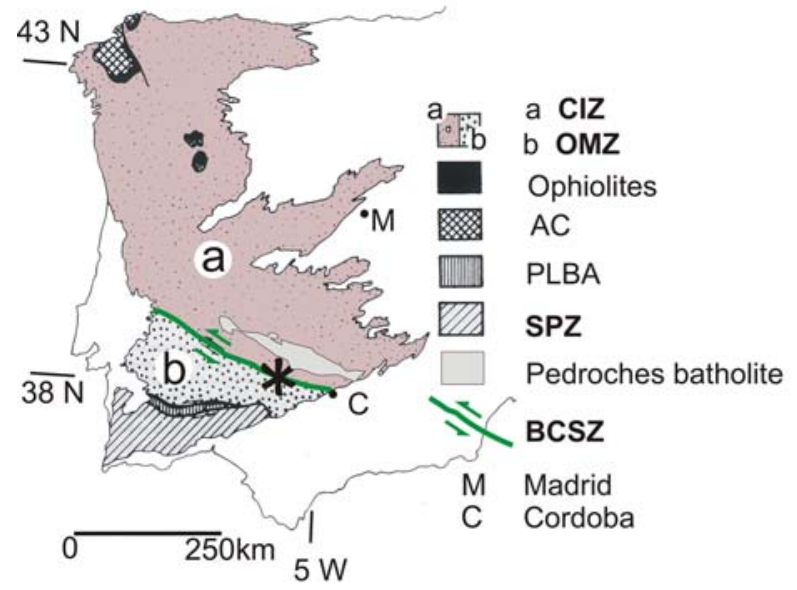

B Badajoz Cordoba Shear Zone BCSZ

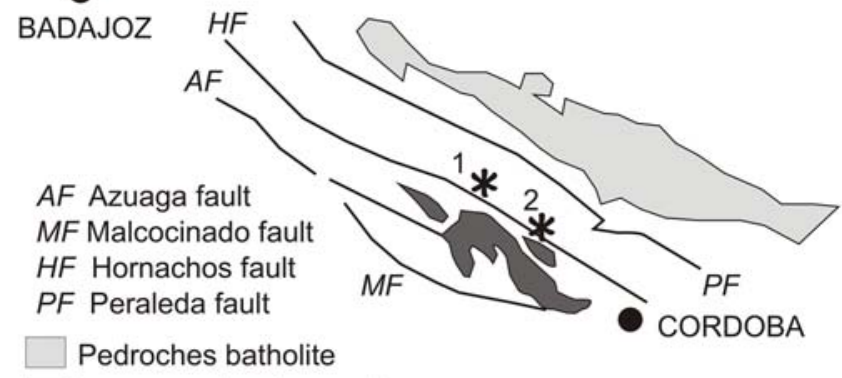

Igneous volcanic complex

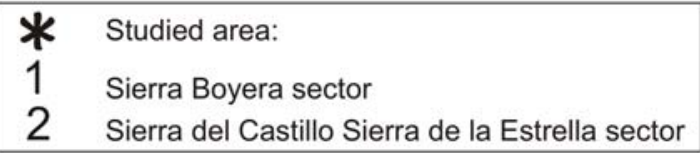

\section{Carboniferous outcrops} from Guadiato Valley

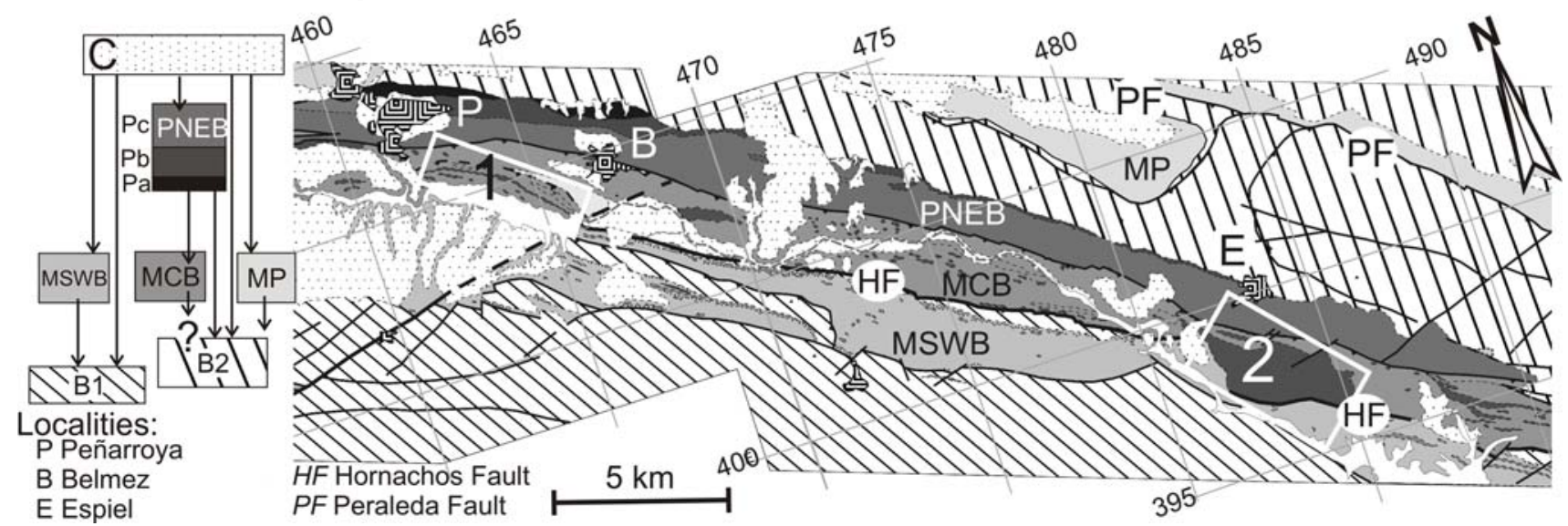

Fig. 1 a Location of the studied area in the Iberian Massif (simplified from Quesada 1992): a CIZ Central Iberian Zone-included West Asturian-Leonese and Cantabrian Zones, $b$ OMZ Ossa Morena Zone, $A C$ Allochthonous Complexes, PLBA Pulo de Lobo terrain and BejaAcebuches Ophiolite, SPZ South Portuguese Zone, BCSZ BadajozCordoba Shear Zone. b Location of the studied area in the BCSZsimplified from Ábalos and Díaz Cusí (1995). c Carboniferous out- crops from the Guadiato Valley (modified and simplified from the MAGNA Geological Map Series, Sheets 879, 880 and 901): $M S W B$ Mississippian South Western Band, $M C B$ Mississippian Central Band, $P N E B$ Pennsylvanian North Eastern Band: $\mathrm{Pa}$ Breccias, $\mathrm{Pb}$ Conglomerates, $P C$ Siltstones, sandstones and coal. $B 1$ and $B 2$ pre-Carboniferous basements with OMZ and CIZ affinities, respectively. $M P$ Carboniferous outcrops from the Pedroches area. $C$ Cenozoic deposits 
reference terms or concepts in the mesostructural study of their internal organization. However, the accretion mechanisms are not so clear when both massive or leiolitic fabrics and aphanitic micritic microfabrics occur simultaneously and are dominant. The presence of peloidal micrites is then argued as microbial-mediation activity, and the possibility of the abiogenic character of the mud mound disappears. However, the focus should be whether peloidal microfabrics were able to produce rigid, accretionary microstructures and how to recognize and quantify these microstructures.

Peloidal matrices have been described both in Recent and fossil bioconstructions (see Riding 2000; Reitner and Neuweiler 1995; Reitner et al. 2000; Folk and Chafetz 2000; Pratt 1995), and their origins have also been discussed for a long time (Monty 1965; Macintyre 1985; Chafetz 1986; Reitner 1993; Kazmierczak et al. 1996). However, there are few microstructural classification schemes based on descriptive parameters in which peloids are the dominant elements (Permian-Triassic: Reid 1987; Adachi et al. 2004; Jurassic: Sun and Wright 1989; Schmid 1996). This would be irrelevant in those bioconstructions dominated by skeletal-frameworks where peloids have a secondary importance and have been interpreted in several ways (peloidal cement and/or peloidal internal sediment in cavities/porosity, peloidal interframe, peloidal microbialitic crust). What were the roles played by the peloidal micrites, in the apparently framesless, peloidal-dominated mud mounds of the Guadiato Valley?

The main objectives of this paper are to show how the classification and detailed mapping of mud mound microfabrics allow us to: (1) recognize the different roles of peloidal micrites, (2) estimate the volume relationship between autochthonous and allochthonous mound carbonate production, and (3) reconstruct the micro-framework of these mud mounds.

\section{Geological setting}

We studied the mud mounds of the Guadiato Valley, which are close to the villages of Espiel and Belmez at NW Cordoba province, in the southern part of the Iberian Massif (Fig. 1a). The Iberian Massif corresponds to the SW part of the European Variscan Orogen, formed as a consequence of the collision between Laurentia and Gondwana during Devonian-Permian times (Matte 1991). The analyzed sedimentary record is located in a narrow band of PrecambrianCarboniferous outcrops, tectonically bounded by the Hornachos and Peraleda faults, which are part of the BCSZ (Badajoz-Córdoba Shear Zone, Fig. 1). The BCSZ is a NW-SE structural band $400 \mathrm{~km}$ in length between Tomar (Portugal) and Córdoba (Spain). This structure is an impor- tant and complex cortical accident and has been, in general, accepted as the limit between the Ossa Morena Zone (OMZ) and the Central Iberian Zone (CIZ) -Iberian Massif divisions (works from Iberian Massif in Ábalos et al. 2002; Pérez-Estaún and Bea 2004). However, the boundaries between OMZ and CIZ have been a source of controversy (San José et al. 2004). The BCSZ has been interpreted as a suture, part of the Cadomian subduction complex, which will later reactivate during the Variscan Orogeny (Quesada 1992) as an intracontinental shear zone (Eguíluz et al. 2000). It has also been interpreted as just a Variscan suture (Azor et al. 2004). CIZ would be interpreted as part of the Gondwana margin whereas the $\mathrm{OMZ}$ is viewed as a terrain related to Gondwana (Simancas et al. 2004).

In the Guadiato Valley, the dispersed and isolated Carboniferous outcrops were first mapped and informally divided into three bands by Pérez-Lorente (1979), probably based on the earlier work by Ortuño (1971). Mississippian outcrops (Fig. 1c) are situated along the southwest and central bands, whereas the northeast band corresponds to the Pennsylvanian ones. Different paleogeographic models have been proposed for the Mississippian outcrops (Gabaldón et al. 1985; Martínez Poyatos et al. 1998; Martínez Poyatos 2002; Cózar and Rodríguez 2003). However, the relationship between the Mississippian central band and its pre-Carboniferous basement is unknown; and there are no lithostratigraphic correlations between both of the Mississippian bands.

The studied peloidal-dominated mud mounds are located in two sectors, both placed in the central band (1 and 2 in Fig. 1c): Sierra Boyera (SB) and Sierra del Castillo-Sierra de la Estrella (SCSE). Most studies carried out in the central band have been focused on paleontology (corals, algae, foraminifers, conodonts), biostratigraphy (mainly foraminifers and corals) and the stratigraphy of the calcareous deposits (Mamet and Martínez-Díaz 1981; Cózar and Rodríguez 1999, 2003, 2004; Cózar and Mamet 2001; Cózar 2003a, 2003b; Cózar and Vachard 2004a, 2004b; Bermúdez-Rochas et al. 2004; Rodríguez et al. 2004). Detailed cartographic, stratigraphic, and sedimentological studies allowed the recognition of five mud mound stages within the Upper Viséan succession of up to $900 \mathrm{~m}$ in thickness (Rodríguez-Martínez 2005).

\section{Methodology}

The mapping of the outcrops was done with enlarged aerial photographs (original scale 1:18,000) to delineate both the mud mound and off-mound facies distribution. Fourteen stratigraphic sections were measured. In total, 1,013 samples were collected (318 from the SB sector and 697 from the SCSE sector). An identical number of thin sections 
were prepared: large thin sections $(5 \times 8 \mathrm{~cm}$ in size $)$ from mud mound samples and standard sizes $(4.6 \times 2.5 \mathrm{~cm})$ from the associated facies. The sampling from the most continuous and complete sections was selected for detailed microfacies analysis (698 thin sections). The analyzed features from both mud mound and off-mound thin sections were: (a) a semi-quantitative estimation percentage of 34 components (visual estimation charts from Flügel 2004); (b) counting the number of specimens per thin section of components at different taxonomic levels (red algae as ungdarellaceans and Fasciella, green algae as Koninckopora, and Incertae sedis as Saccamminopsis); (c) qualitative estimation of small and rare calcimicrobes (Girvanella, Renalcis) and problematic taxon such as Aphralysia.

The maps of mud mound microfabrics were drawn directly over the thin sections under the stereomicroscope (more than 200 thin-section maps). Each type of microfabric was codified and numbered, and the resulting mapped thin sections with their codes were photocopied. The photocopies were digitalized and re-drawn with CorelDRAW software.

\section{Mud mound stratigraphic record}

The Mississippian succession from the SB and SCSE sectors has been informally divided into three groups $(1,2$, and 3 in Fig. 2): (1) lower heterolithic units, (2) middle carbonate units, and (3) upper heterolithic units. Mud mound facies occur in the lower and middle units and comprise five megastructural stages, from the base to the top (A-E in Fig. 2): (A) mud mound-derived boulders, (B) tabular banks and associated breccias, (C) isolated-pinnacles belt, (D) amalgamated-bioherms belt, and (E) isolated-bioherms belt. The first two mud mound records (A, B in Fig. 2) occur in both sectors whereas the rest of the stages (C-E in Fig. 2) were only developed in the SCSE sector.

Lower heterolithic units (up to $180 \mathrm{~m}$ in thickness) start with moderately channelized to sheet-like bodies of internally massive poorly sorted, pebble-cobble, mainly clastsupported polymictic conglomerates. The conglomerates grade into centimeter-scale tabular beds of calcarenites, lenticular beds of granule-pebble polymictic conglomerates, and interbedded marls, forming a fining upwards interval. It is followed by slumped levels and massive cobble-boulder polymictic megabreccias. The size and composition of clasts in the megabreccias vary from angulose to well-rounded sandstone and calcarenites pebbles, quartzite pebble-cobbles, and large metric mud mound-derived boulders (A in Fig. 2). The top of the lower heterolithic units corresponds to massive oolitic limestones with sandstone pebbles, which overlain unconformity the previous megabreccias.

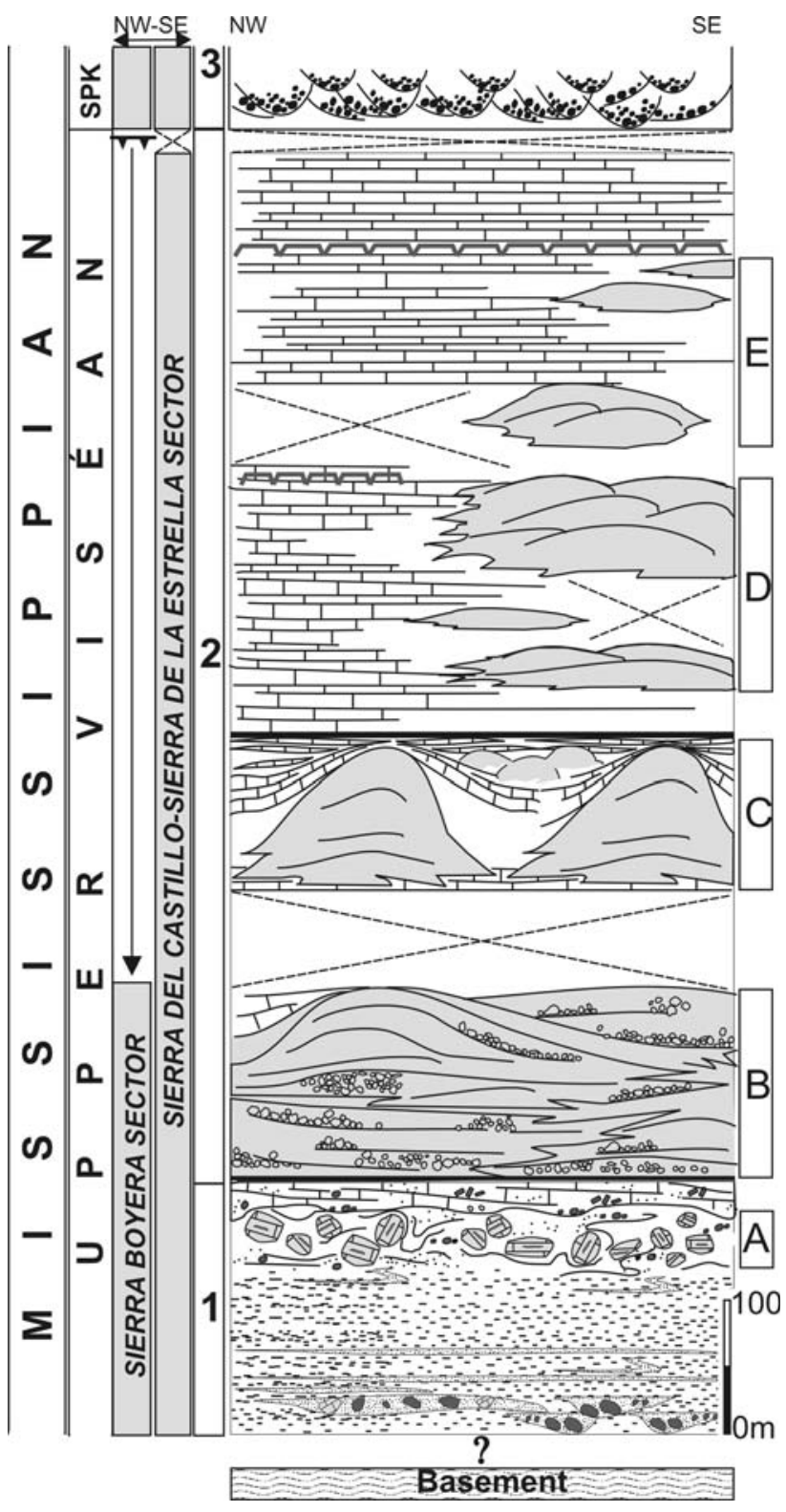

Fig. 2 Stratigraphy of the upper Viséan mud mound record from the Guadiato Valley: 1 lower heterolithic units; 2 middle carbonate units; 3 upper heterolithic units. $A-D$ Megastructural mud mound stages: $A$ mud mound-derived boulders; $B$ tabular banks and the associated breccias; $C$ isolated-pinnacles belt; $D$ amalgamated-bioherms belt; $E$ isolated-bioherms belt

The middle carbonate units are always tectonically bounded. Thickness ranges from $60 \mathrm{~m}$ in the SB sector to up to $700 \mathrm{~m}$ in the SCSE sector. Middle carbonate units have four mud mound phases (B-E in Fig. 2). Stage B has $130 \mathrm{~m}$ of maximum thickness and from 500 to $2,340 \mathrm{~m}$ in width in the SB and SCSE sectors, respectively. Basal beds correspond to black, well-bedded wackestones to packstones, which grade into the mud mound facies. The last ones are formed by massive bank intervals 5-20 m thick, interbedded with mud mound-derived monomictic breccia 
intervals of up to $5 \mathrm{~m}$ thick. Because stage B is always tectonically bounded, the stratigraphic relationship with the coeval off mound record is unknown.

The base of stage C (Fig. 2) begins with pelmatozoanrich deposits. Stage $\mathrm{C}$ is formed by four isolated pinnacle mud mounds, close intermound facies, and off-mound coeval well-bedded limestones. Pinnacles have $110 \mathrm{~m}$ of maximum thickness and range from 144 to $555 \mathrm{~m}$ in width. At the top, pinnacles show flank facies development, and, in the flank facies, small interbedded satellite mud mounds occur.

The following mud mound megastructural stage (D in Fig. 2) starts after an interval of marls with interbedded black wackestones. Mud mound facies reach $180 \mathrm{~m}$ in thickness and extend up to $3,000 \mathrm{~m}$ in width. They are organized in lenticular to hemispheroid 1-3 m thick bodies, vertically stacked in 5-60 m thick intervals.

The last mud mound stage, in the middle carbonate units, corresponds to isolated bioherms (E in Fig. 2) and off-mound coeval limestones. Bioherms are up to $35 \mathrm{~m}$ of vertical stacking and $250 \mathrm{~m}$ in width. The upper part of the middle carbonate units consists of well-bedded limestones, texturally and compositionally varied. The boundary between the middle carbonate units and the upper heterolithic units is covered in the SCSE sector and corresponds to a thrust in the SB sector. The upper heterolithic units (3 in Fig. 2) correspond to sandy calcarenites, limestones, and channel bodies of pebble and cobble siliciclastic conglomerates, sandstones, and siltstones with bedding planes rich in plant remains.

In outcrop scale and hand-polished samples, these mud mounds have a massive or cryptalgal mesostructure (scales according Shaphiro 2000). Macrofossil content is really very scarce and dominated by pelmatozoan remains. Only mud mound-derived boulders (stage A in Fig. 2) have a significant amount of sponges, solitary and colony corals, brachiopods, and gastropods, all of them with a patchy cluster distribution that never forms a skeletal framework. The content in skeletal (microfauna and microflora) and nonskeletal grains of Guadiato mud mounds is around $25 \%$ of the rock volume average (Fig. 3a). However, in most cases (more than 50\%), these grains are just accessory components $(<1 \%$ of the rock volume), and only some of them have volume averages of $5-10 \%$ in the A and B stages (Fig. 3b).

\section{Mud mound microfabrics}

In general, most of the mud mound microfabrics show an elevated degree of heterogeneity. In a few centimeters, fast microfabric changes occur, such as a patch of fenestellid cementstone surrounded by biomicrites, which grades into
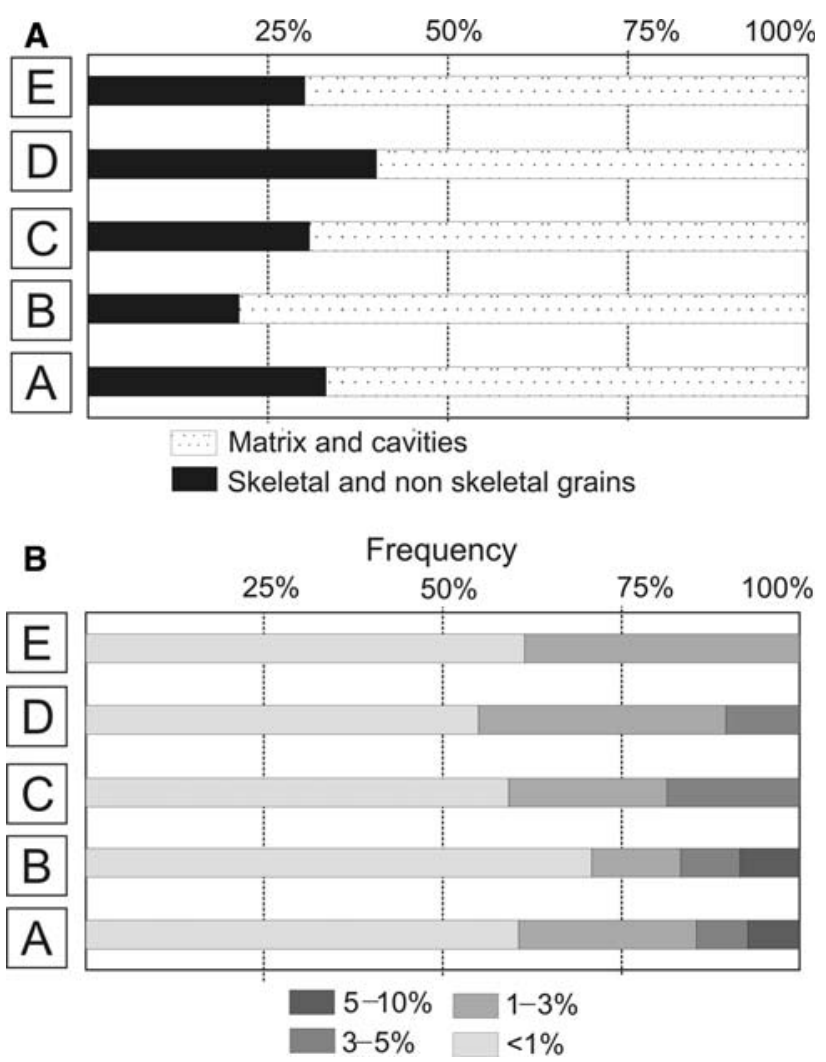

Fig. 3 a Rock volume average of matrix-cavities and skeletal/nonskeletal grains, in each mud mound stage ( $A-E$ as in Fig. 2). b Frequency of every volume average class from skeletal and non-skeletal grains in mud mound stage $A-E$. Most of the grains (50\%) occur as accessory components $(<1 \%$ of the rock volume)

a pelsparitic cavity filling, where the roof can be partially supported by skeletal remains (some of them covered by fine peloidal crusts). In this hypothetical case, the mud mound is composed of different carbonate fractions (skeletal grains, peloids, micrite, and cement) where peloids can occur isolated in the biomicrites, as part of the cavity filling as well as forming the crust. In addition, giving a final general microfacies name that responds to this heterogeneity on the microscale can be not only difficult but also unrealistic in descriptive terms.

The spectrum of Guadiato mud mound microfabrics are described below as peloidal-, intraclastic-, bioclastic-dominated, and micritic microfabrics.

\section{Peloidal-dominated microfabrics}

The peloidal-dominated microfabrics (Figs. 4, 5a-g) are those where $\geq 50 \%$ of the rock volume is formed by the peloidal fraction (fine and/or coarse peloids). The peloidal fraction is composed of spherical to ellipsoidal peloids 10 $100 \mu \mathrm{m}$ in diameter. The distribution of peloidal sizes can be homogeneous or heterogeneous (a mixture of sizes). 

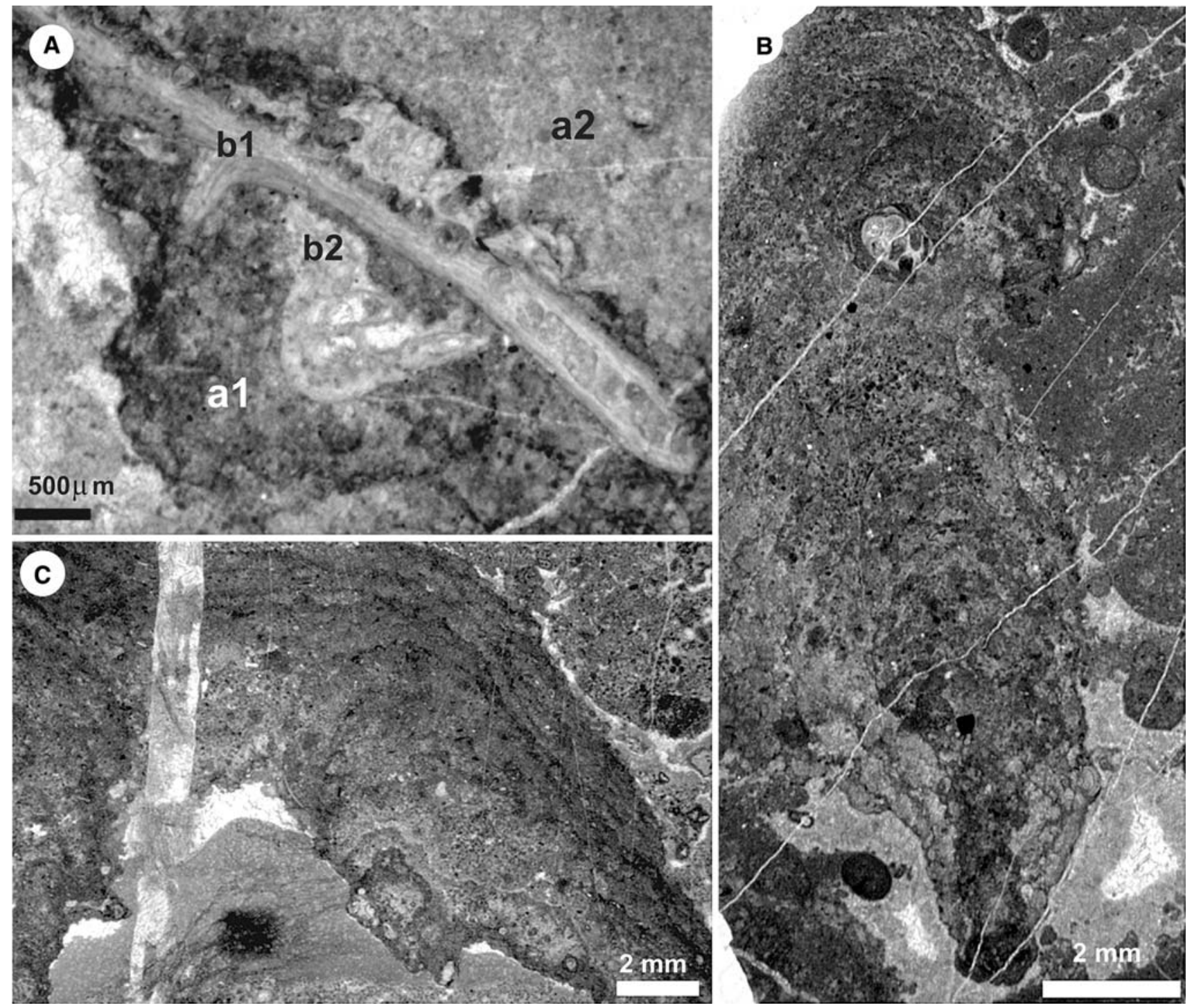

and small cavities with marine fibrous cements in the lower part of the

Fig. 4 Examples of different growth morphologies of the fine peloidal microfabrics: a crusts (al and $a 2$ ) around bryozoans (b1 and $b 2)$; b microcolumn development with serpulids (center in the upper part) picture; c massive to internally laminated microdome, partially supporting a growth cavity with a micrite geopetal filling
Fine peloidal microfabrics

The size of peloids varies from 10 up to $70 \mu \mathrm{m}$, with an average of $20 \mu \mathrm{m}$. The microfabric subtypes have been divided on the basis of the peloid: cement ratio, the matrixor cement-supported character. A total of three fine peloidal microfabric subtypes have been recognized from densely packed to cement-supported subtypes (70:30; 50:50; and 20:80 peloid: cement ratios; see Fig. 5a-c). Normally, all of them appear associated and grading into each other.

Fine peloidal microfabrics may form crusts from $1 \mathrm{~mm}$ up to $5 \mathrm{~mm}$ in thickness around skeletal remains (Fig. 4a) and commonly appear associated with encrusting bryozoans and sponges. In turn, crusts can also be colonized by microencrusters like foraminifers and others of unknown origin. Fine peloidal microfabrics also occur within the cavity system, in anti-gravitational relationship, as the substrate of marine fibrous cements and in a geopetal relationship as a part of the filling sequence. Secondary porosity, such as fractures and interclastic spaces in breccias, can display fillings of these microfabrics in some mud mound stages. Isolated microdomes $(3 \times 2 \mathrm{~cm}$ of maximum size $)$, microcolumns $(1 \times 2 \mathrm{~cm}$ of maximum size $)$, and more complex reticulate forms are built by the homogeneous fine peloidal microfabrics (Fig. 4b, c). Microdomes can be internally laminated or not. Most of the time, the lamination corresponds to an irregular and discontinuous thin lamination. However, laminae, which range from 200 to $400 \mu \mathrm{m}$ can be recognized. Lamination results from both packed- and size-changes of the peloids. Each lamina 
Homogeneous microfabrics:

Peloidal types

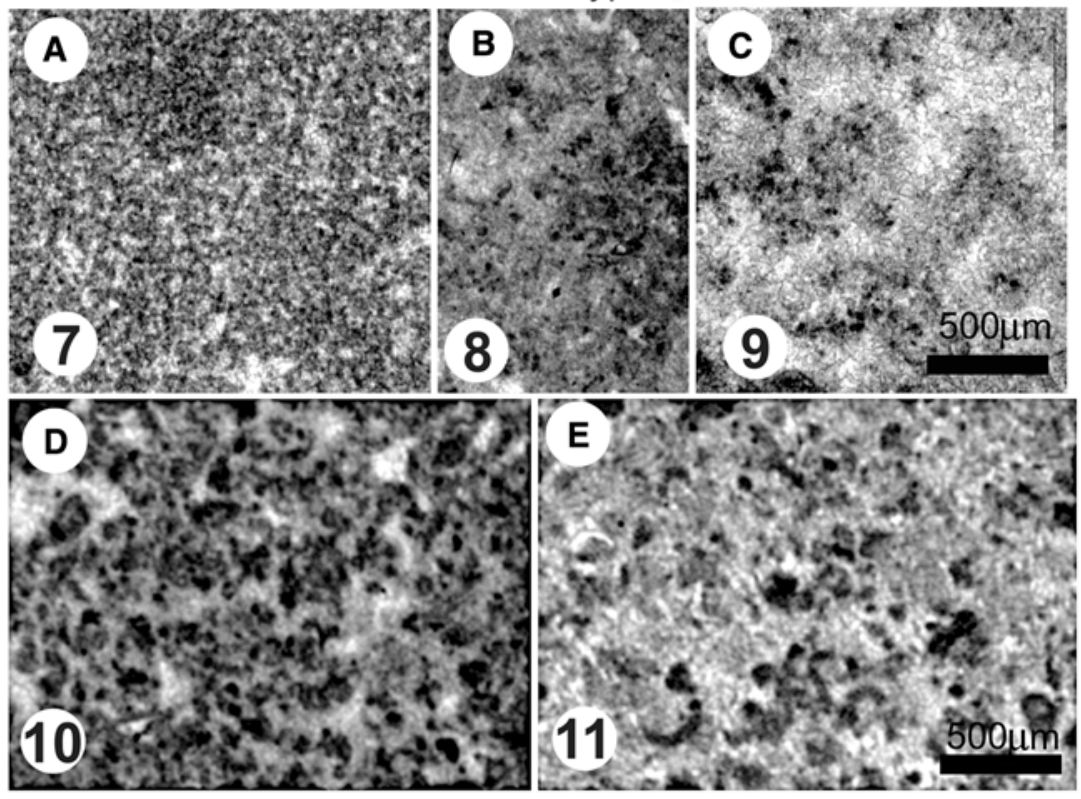

Heterogeneous microfabrics:
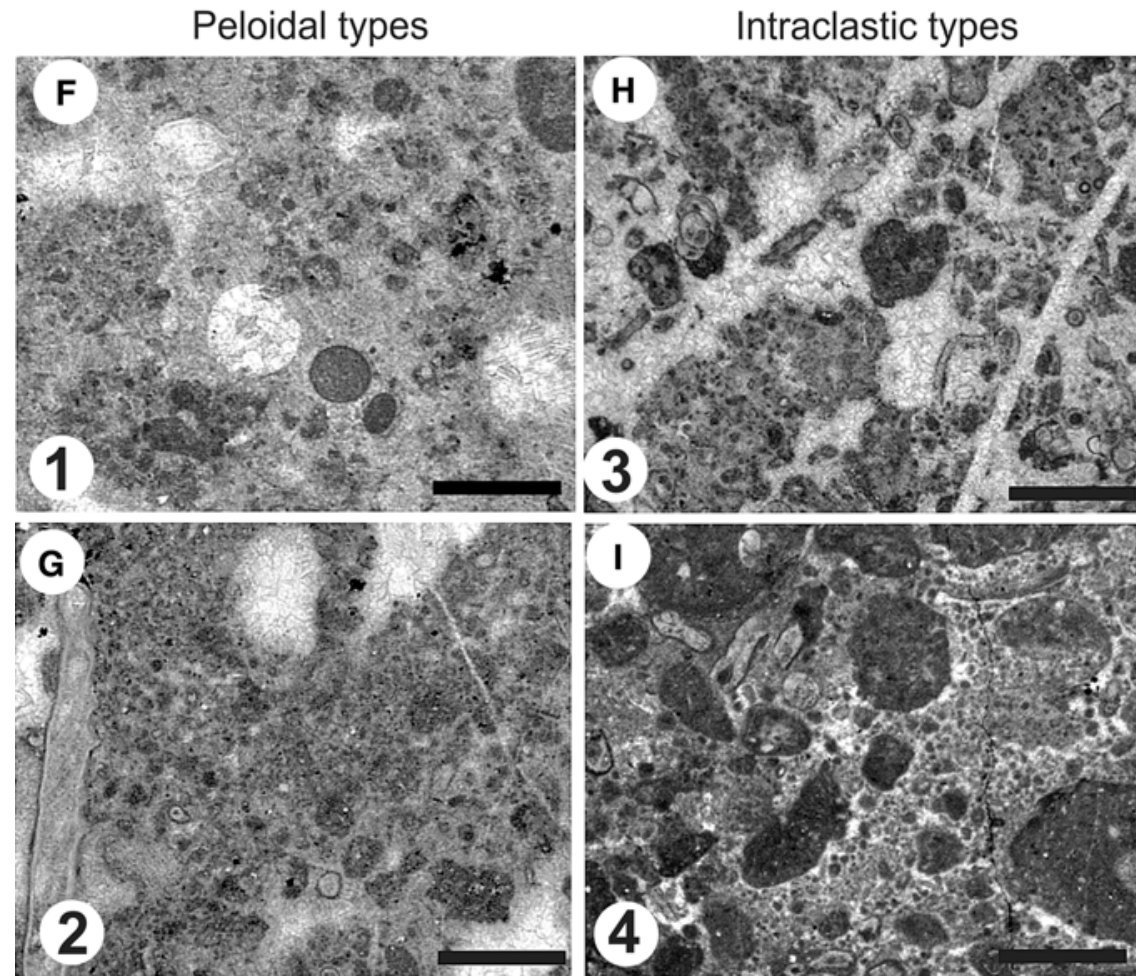

Bioclastic types
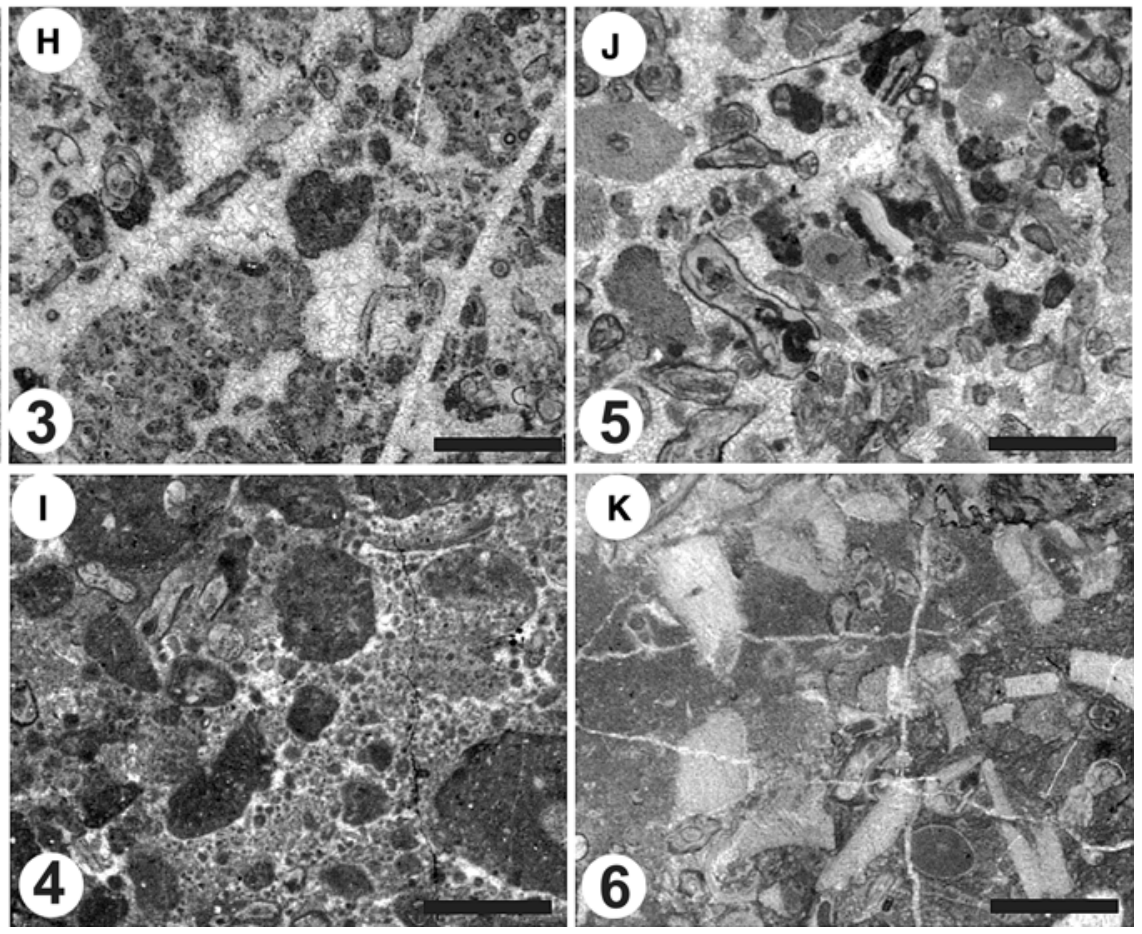

Fig. 5 a-e Peloidal-rich mud mound microfabrics with a homogeneous distribution of the size of peloids: $\mathbf{a}-\mathbf{c}$ fine peloidal microfabrics from the matrix to the cement-supported varieties ( $\mathrm{m}-\mathrm{s}$ and $\mathrm{c}-\mathrm{s}$, respectively); d, e coarse peloidal microfabrics (m-s and c-s, respectively). $\mathbf{f}-\mathbf{k}$ Heterogeneous mud mound microfabrics: $\mathbf{f}$, $\mathbf{g}$ heterogeneous coarse peloidal microfabrics (c-s and m-s subtypes); $\mathbf{h}, \mathbf{i}$ heterogeneous intraclastic microfabrics (c-s and m-s subtypes); $\mathbf{j}$, k heterogeneous bioclastic microfabrics (c-s and m-s subtypes). Graphic scale bars are $1 \mathrm{~mm}$ in the $\mathbf{f}-\mathbf{k}$ pictures. Numbers in pictures represent the assigned codes during the mapping of the thin sections; see Fig. 6 
starts with a clear, less packed peloidal interval (up to $50 \mu \mathrm{m}$ for the diameter size of the peloid) and is gradually followed by a dark, densely packed interval with peloids from 10 to $20 \mu \mathrm{m}$ in size.

\section{Coarse peloidal microfabrics}

We use the term coarse peloidal microfabrics when the distribution of the size of peloids ranges in diameters from 30 to $100 \mu \mathrm{m}$. The coarse peloidal microfabrics are divided into two subclasses: homogeneous coarse peloidal microfabrics (Fig. 5d, e) and heterogeneous coarse peloidal microfabrics (Fig. 5f, g).

Homogeneous coarse peloidal microfabrics develop the cement as well as the matrix-supported subtypes (c-s and $\mathrm{m}$-s, respectively). The diameter sizes of peloids on the cement-supported type are slightly larger, with an average of $55 \mu \mathrm{m}$, in contrast to $40 \mu \mathrm{m}$ for the matrix-supported type. Enclosed bioclastic content is low and generally formed by ostracod valves. Fecal pellets can be locally abundant and non-skeletal grains like peloidal intraclasts also occur.

Homogeneous coarse peloidal subtypes have always been observed as associated with the filling cavity system and generally in geopetal relationship. The cement-supported type can also appear in anti-gravitational relation to the cavities. Some large reticulate cavities are particularly characterized with the filling of this peloid type that can or not occur banded. Irregular bands are the result of differences in both peloid size and packing, but banding is also a result of the changes in the microfabric type, when interbedded sequences of the c-s and m-s subtypes occur. The contact surface, or transition, in these interbedded sequences can correspond to gradual or abrupt limits. The thickness of the bands varies from a few millimeters up to $2 \mathrm{~cm}$ in some cases. The c-s subtype sometimes shows interruptions as micritized surfaces and fibrous cement developments.

The heterogeneous coarse peloidal microfabrics are characterized by the heteromodal distribution of sizes and by the mixture of the different components (peloidal, intraclastic, and bioclastic fractions, which are $\mathrm{P}, \mathrm{I}$, and $\mathrm{B}$, respectively). Heterogeneous coarse peloidal microfabrics are represented by a 50:25:25 PIB ratio and occur as c-s and m-s subtypes (Fig. 5f, g, respectively). The coarse peloids are around $50 \mu \mathrm{m}$ in size on average, although all sizes are mixed and randomly distributed. The presence of irregular clusters, patches of fine peloids, generally $1-2 \mathrm{~mm}$ in size, is common. Clusters are surrounded by small acicular cement rims and inter-cluster spaces define irregular-shaped pores also lined by fibrous rims. In these microfabrics, the skeletal grains are not oriented and show no evidence of hydraulic sorting. Non-skeletal grains, such as fecal pellets, are ubiquitous. Agglutinated worm tubes, described as Terebella-like structures, are also common. Diverse cavity typologies are well developed such as matrix-supported stromatactis-like and shelter-type cavities (related to brachiopods, bryozoans, and sponges).

\section{Intraclastic-dominated microfabrics}

Irregular peloidal intraclasts, not angular in shape and with diffuse margins, are the dominant elements in the heterogeneous intraclastic microfabrics that have a 25:50:25 PIB ratio. The irregular intraclasts are randomly distributed and surrounded by fine and coarse peloids. The intraclasts are identical to the surrounding matrix; thus, they can be as large as $2 \mathrm{~mm}$ in some cases, but they are normally found in the $500-1,000 \mu \mathrm{m}$ interval.

The heterogeneous intraclastic microfabrics also display the c-s and m-s subtypes (Fig. 5h, i, respectively). These microfabrics occur with a patchy distribution: (1) as basal geopetal filling in large cavities, (2) associated with fractures and brecciated areas, and (3) grading and interbedded with other microfabrics.

\section{Bioclastic-dominated microfabrics}

The most heteromodal distribution of component sizes occurs when the skeletal content is high and the PIB ratio is around 25:25:50. Bioclastic-dominated microfabrics develop c-s and m-s subtypes (Fig. 5j, k) and show a patchy distribution. As previously indicated, the volume contribution of skeletal grains is low (Fig. 3a, b). Crinoids, and occasionally sponges in some megastructural stages, are secondary components $(5-10 \%$ of rock volume on average). Minor components are fenestellid bryozoans (3-5\% of rock volume on average) as well as ostracods, calcareous algae, brachiopods, and burrows (1-3\% of rock volume on average). Ramose and encrusting bryozoans, echinoid spines, brachiopod spines, foraminifers, gastropods, trilobite fragments, and solitary and tabulate corals are accessory components $(<1 \%$ of rock volume on average). They occur with a patchy distribution, and only few components can occasionally reach high concentrations. The particular situation where the skeletal and cement volume ratio is around 1:1 has only been observed with fenestrate bryozoans and the Incertae sedis Saccamminopsis.

\section{Micritic microfabrics}

When micrite $(<4 \mu \mathrm{m})$ and/or microspar $(4-31 \mu \mathrm{m})$ are the dominant components, the resulting microfabric corresponds 
to mudstones or wackestones. Micrite is common as geopetal internal sediment in cavities. It also forms isolated patches grading laterally into other microfabrics, and it is associated with secondary porosity related to fractures. Micrite in cavities can occur as the only geopetal infilling, as successive micritic infillings, or alternating with other microfabrics. It can also occur as mudstone-wackestone fining-upwards sequences. The mud mound micritic fraction shows no optical differences with the micrite observed in the coeval off-mound deposits.

\section{The micro-framework reconstruction}

As it was shown before, peloids characterized several microfabrics which can grade into one another in a few centimeters. The classification and the detailed mapping of these microfabrics can help to recognize their internal spatial distribution, quantify the volumetric relationship between the automicrite production and the allomicrite input, and reconstruct the micro-framework.

\section{Classification and mapping}

For the mapping of the thin sections, as it has been described through the previous chapters, the classification of microfabrics was made on the basis of the following categories: (1) homogeneous or heterogeneous distribution of sizes, (2) main carbonate fraction (peloidal, intraclastic, bioclastic, and micritic ones), and (3) type of final 'support' (matrix or cement-supported character). The resulting microfabric subtypes were codified with numbers (Figs. 5, 6); however, the numbers are not related to the temporal organization of the microfabrics. A total of 13 microfabrics were separated and mapped (Fig. 6): (1) homogeneous fine peloidal microfabrics (subtypes 7, 8, and 9); (2) homogeneous coarse peloidal microfabrics (subtypes 10 and 11); c) heterogeneous coarse peloidal microfabrics (subtypes 1 and 2); (3) heterogeneous intraclastic microfabrics (subtypes 3 and 4); (4) heterogeneous bioclastic microfabrics (subtypes 5-6); and (5) micritic microfabrics (subtypes 12 and 13, mudstone and wackestone, respectively). Dolomicrite is quite uncommon and was codified as number 14 .

Marine fibrous cements associated with the cavity system were also mapped and estimated. They correspond to acicular and fibrous types forming isopachous as well as irregular crusts in cavities, and also as isopachous rims around skeletal components. Radiaxial fibrous cements also appear as thick rims in the cavity system. They are turbid, inclusion-rich crystals and they exhibit undulose extinction. Both radiaxial fibrous and fascicular-optic calcite extinction patterns have been recognized. All of them were codified as 15 (Fig. 6).

\section{Autochthonous production versus allochthonous sedimentation}

In the Upper Viséan mud mounds from Guadiato Valley, the homogeneous fine peloidal microfabrics (subtypes 7, 8, and 9; Figs. 4, 5a-c) correspond to automicrites or autochthonous microcrystalline carbonates formed in place. Automicrites have been interpreted as the result of different genetic modes of production (see summarized in Flügel 2004, pp. 81-88): (1) physicochemical precipitation (e.g.: Macintyre 1985), (2) in-place mineralization via organic matrices (organomicrites sensu Reitner 1993; see organomineral definition comment in Défarge et al. 2009), and (3) via metabolic processes related to microbial benthic communities causing carbonate precipitation (Castanier et al. 1999; Chafetz 1986; Pomar and Hallock 2008). Petrographically, the possible origins are not possible to recognize because different processes result in similar end products.

The homogenous coarse peloidal fabrics (subtypes 10 and 11 -Figs. 5d, e, 6) represent the internal sedimentation and production of automicrites that are exclusively developed in the cavity system. The type of 'support' is related to the relationship between the sedimentation, production, and the cementation rate in the cavity: matrix-supported types occur for high and continuous rates of automicrite sedimentation and production, whereas low and discontinuous rates produce the cement-supported type. In the cavity, the transition from the matrix-supported to the cement-supported type could also represent an increase in water pumping that favored marine cementation.

The heterogeneous microfabrics (subtypes 1-2, 3-4, and 5-6-Fig. 5f-k) show evidence of a mixture of processes: (1) autochthonous production of fine peloids in the pores and pockets, (2) early lithification (the development of matrixsupported growth cavities, synsedimentary fractures with marine infillings, brecciation, and early marine cementation), (3) a volumetrically diverse skeletal contribution (both autochthonous and parautochthonous assemblages occur), (4) an external skeletal contribution (allochthonous assemblages which have loose platform-shed components), and (5) reworking (peloidal intraclast production, burrowing, winnowing into the cavity system). All of these processes reveal an asymmetrical balance between the constructive and destructive processes where the autochthonous processes are dominant. The heterogeneous intraclastic subtypes are common in the stages when vertical accretion is dominant (stage $\mathrm{C}$ in Fig. 2), whereas the heterogeneous bioclastic subtypes are more common in stages characterized by lateral accretion (stages D and E in Fig. 2). Thus, 


\begin{tabular}{|c|c|c|c|c|c|c|}
\hline & \multicolumn{4}{|c|}{ Distribution of sizes } & \\
\hline & & \multicolumn{4}{|c|}{ Heterogeneous } & \\
\hline & & \multicolumn{5}{|c|}{ Main carbonate fraction } \\
\hline & & \multicolumn{2}{|c|}{ Peloidal } & Intraclastic & Bioclastic & Micritic \\
\hline $\begin{array}{l}\mathrm{S} \\
\mathrm{u} \\
\mathrm{p}\end{array}$ & $\begin{array}{ll}\varphi \\
\underline{p} \\
\end{array}$ & $\begin{array}{r}7 \\
10 \\
\end{array}$ & 2 & 4 & 6 & 1213 \\
\hline $\begin{array}{l}\mathrm{p} \\
\mathrm{o} \\
\mathrm{r}\end{array}$ & $\underline{s}$ & $\begin{array}{l}8 \\
9\end{array}$ & 1 & 3 & 5 & $\begin{array}{l}\text { Marine fibrous } \\
\text { cements }\end{array}$ \\
\hline $\mathrm{t}$ & & & & & & 15 \\
\hline
\end{tabular}
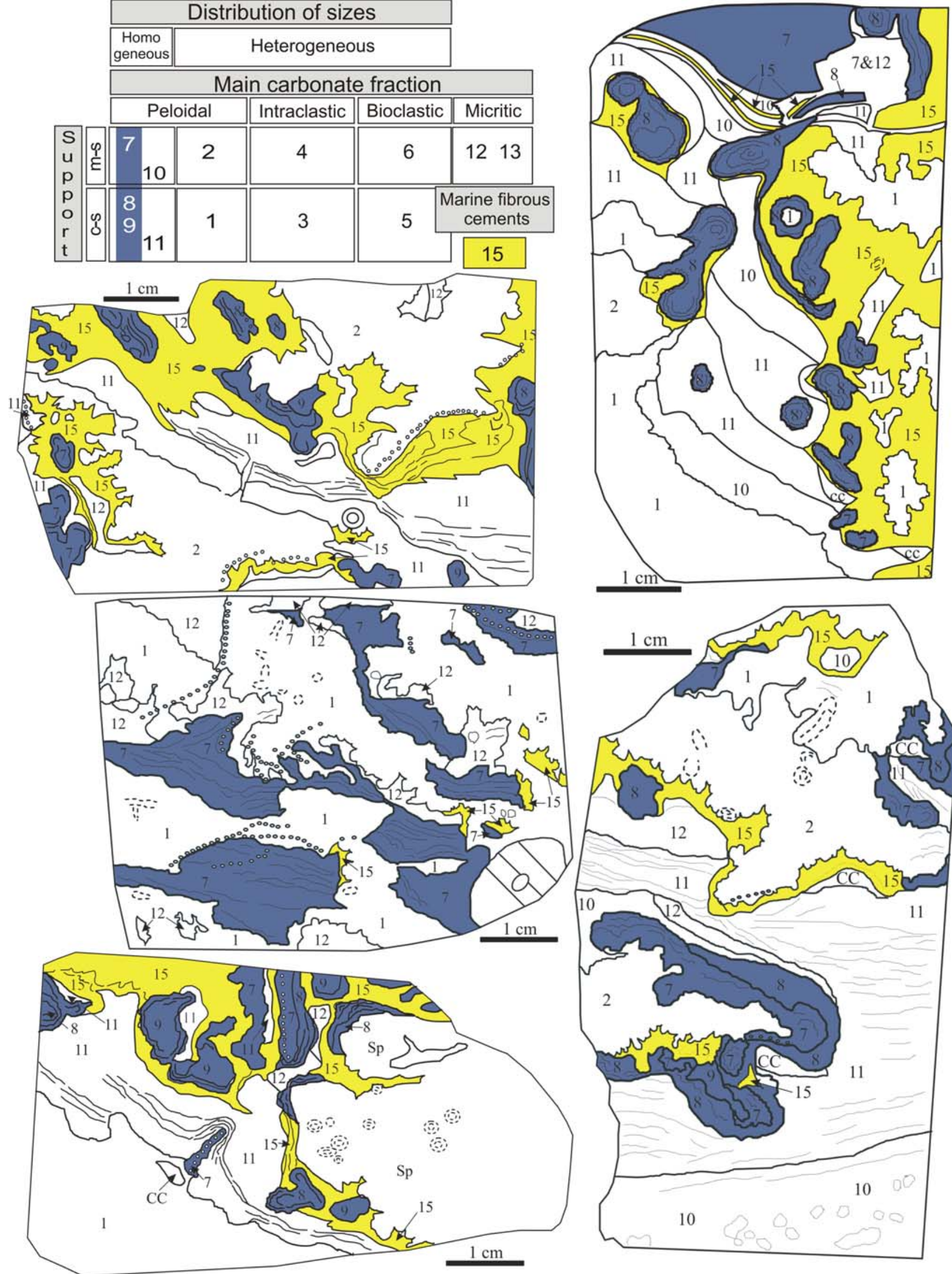
4 Fig. 6 Classification and numeric codes of mud mound microfabrics. The classification categories are: (1) the distribution of sizes; (2) the compositional fraction (peloidal, intraclastic, bioclastic, and micritic); and (3) the matrix or cement-supported character (m-s and c-s, respectively). Examples of thin-section maps with the distribution of codified microfabric areas

heterogeneous intraclastic microfabrics could indicate major gravity and/or hydrodynamic reworking rates, whereas the heterogeneous bioclastic subtype could reflect more suitable conditions to colonize the substrate by non-microbial benthic communities as well as a greater input of shallow-water platform-derived grains. Heterogeneous microfabrics are autochthonous microfabrics, with automicrite production, but signals of microfabric reworking (physical, biological, and/or diagenetic processes) also occur.

Finally, the micritic microfabrics (subtypes 12 and 13), where micrite shows no any recognizable accretional forms, most part of the cases records hydrodynamic, gravitational or synsedimentary deformation features (oriented bioclasts, geopetal fillings, angulose intraclasts), and shows no petrographic differences with the off-mound record, are interpreted here as allomicrites as a part of the external sedimentation input recorded in the Guadiato mud mounds.

\section{Comparison}

Homogeneous peloidal microfabrics have not only been described in mud mounds, but they have also been described in Recent microbialites (Reitner 1993), coral reefs (Cabioch et al. 2006; Camoin et al. 1999), and methane-seep deposits (Cavagna et al. 1999; Peckmann et al. 2007). The modes of fine peloidal microfabric growth are constructive structures (crusts, microdomes, and microcolumns). Thus, the homogeneous peloidal microfabrics have been compared with stromatolitic, thrombolitic, and encrusting growth mechanisms (Table 1) linked with the calcifying of microbial biofilms, intense bacterial tissue decay of sponges and matrix-mediated mineralization in general. In spite of the different modes and loci formations, homogeneous peloidal microfabrics (fine and coarse types) have sometimes been called by descriptive and/or genetic names (Table 1).

In Carboniferous outcrops, the oldest figuration of the homogeneous coarse peloidal types was made by Gürich (1906) from Viséan bioconstructions in the Namur province. The Chondrostroma problematicum Gürich, (1906) as well as the Spongiostroma ovuliferum Gürich (1906), exhibit close similarities with the homogeneous coarse peloidal microfabrics. Gürich related the common fecal

Table 1 Comparison of homogeneous peloidal microfabrics with some selected Carboniferous and other bioconstructions

\begin{tabular}{|c|c|c|}
\hline $\begin{array}{l}\text { Homogeneous } \\
\text { peloidal microfabrics }\end{array}$ & Carboniferous examples & Other examples \\
\hline \multicolumn{3}{|l|}{ Fine peloids } \\
\hline \multicolumn{3}{|l|}{ Subtype 7} \\
\hline Microdomes & $\begin{array}{l}\text { Hummocky/crinkled microstructures } \\
\text { of clotted micrite and fine peloids [1] } \\
\text { Peloidal-rich sediment within } \\
\text { encrustation or microbial incrustation [2] } \\
\text { Pseudo-stromatolitic/thrombolitic } \\
\text { structures of fine-grained peloidal } \\
\text { fabrics [3] }\end{array}$ & $\begin{array}{l}\text { Hemispheroids of dense micritic/ } \\
\text { fenestral microbialites [9] } \\
\text { Peloidal micrites showing dome-shaped } \\
\text { algal microstromatolites [10] } \\
\text { Accretionary organomicrites [11] }\end{array}$ \\
\hline Crusts & & $\begin{array}{l}\text { Dense peloidal crusts [12] } \\
\text { Laminated peloidal microbial } \\
\quad \text { crust or non-skeletal stromatolites [13] }\end{array}$ \\
\hline Subtype 8 & $\begin{array}{l}\text { Encrusting microbialites [4] } \\
\text { Microbial incrustations [5] } \\
\text { Micrite crusts in Type B boundstones [6] }\end{array}$ & \\
\hline Subtype 9 & & Cement-supported pelletoidal network [14] \\
\hline \multicolumn{3}{|l|}{ Coarse peloids } \\
\hline Subtypes 10 and 11 & $\begin{array}{l}\text { Chondrostroma problematicum }[7] \\
\text { Spongiostromata ovuliferum }[7] \\
\text { Loose bacterial/algal peloids }[1] \\
\text { Internal sediment }[2,5] \\
\text { Microbial? peloids }[8]\end{array}$ & $\begin{array}{l}\text { Laminated mudstones [15] } \\
\text { Dense micritic/peloidal microbialites [9] } \\
\text { Coarse grained peloidal/detritic microbialite } \\
\quad \text { or crust type } 1[12] \\
\text { Container organomicrites [11] } \\
\text { Peloidal crust-boundstone [16] }\end{array}$ \\
\hline
\end{tabular}

[1] Bridges and Chapman (1988); [2] Somerville et al. (1992); [3] Horbury (1992); [4] Mundy (1994); [5] Pickard (1996); [6] Della Porta et al. (2003); [7] Gürich (1906); [8] Lees and Miller (1995); [9] Neuweiler (1993); [10] García-Mondéjar and Fernández-Mendiola (1995); [11] Reitner et al. (1995); [12] Leinfelder et al. (1994); [13] Nose et al. (2006); [14] Bourque and Gignac (1983); [15] James and Ginsburg (1979); [16] Koch et al. (1994) 
pellets present in both species with stercomes, the waste products derived from the xenophyophores. They are giant, multinucleate, agglutinated rhizopods that excrete a slimy substance. They are typical benthic deposit feeders in the deep sea. They are commonly found associated with seamounts, ridges, canyons, topographic highs in general, and are very abundant in the bathyal north east Atlantic Darwin Mounds today (Hughes and Gooday 2004).

Heterogeneous microfabrics are characteristic mud mound microfabrics and have been referred to in various ways, mainly using Dunham's and Folk's classification terms, such as peloidal mudstone/wackestone, pelsparite, and biomicrite. The presence of cavities and pores has often been a noteworthy characteristic in the final name, for example, stromatactis-bearing wackestone, fenestral biomicrite. Some of these textural terms are used as prefixes of biolithite (Pratt 1995) as well as boundstone terms (boundstone type A in Della Porta et al. 2003), and they reflect the author's conception of the mud mound. When the heterogeneous bioclastic microfabrics are formed by about a $1: 1$ skeletal/cement volume relationship, they are called skeletal/ non-skeletal organism-type name + cementstone (Fagerstrom 1987) or biocementstone (Tsien 1981; Webb 1996). In Guadiato mud mounds, only Saccamminopsis and fenestrate bryozoans form cementstones where they play a scaffold constructor role (Rodríguez-Martínez et al. 2003). Other delicate organisms have played similar role in the so-called biocementstone frameworks (Webb 1996), common framework in mud mounds.

\section{Micro-framework contribution: the roles of the peloidal matrix}

The mud mounds comprise both soft (allomicrites and automicrites) as well as early indurate carbonate muds (automicrites), which can be reworked after their formation, resulting in parautochthonous muds. Homogeneous fine peloidal types show no evidence of bio and/or physical reworking, so they are primary or original microfabrics, considered here to be primary automicrites. However, heterogeneous types show signs of biological and physical reworking, clusters of fine peloidal production in pores, evidence of colonization by non-microbial communities, and/ or external skeletal input. Thus, they are secondary, or modified, reworked or colonized microfabrics and are therefore considered herein as secondary automicrites (a mixture of the previous ones, parautochthonous automicrites). They represent soft substrates that were quickly lithified as the development of matrix-supported cavities makes clear.

The framework scenario (Fig. 7) is built by successive production of firm, primary automicrites, with different accretional morphologies (clusters, crusts, microcolumns, and microdomes), which alternate and develop between and within the secondary automicrites and into the growth cavity system. In the cavities, autochthonous internal sediment (homogeneous coarse peloidal microfabrics) and marine fibrous cements also contribute to the rigidity of the final meshwork. In fact, the cavity filling records many of the last synsedimentary episodes that occurred in the mud mound: the (1) production of cryptic automicrites, (2) colonization by cryptic biota, (3) reworking processes, (4) entry of allomicrite by gravity or currents, and (5) early marine cementation stages and so forth.

Peloidal-dominated mud mounds from the Guadiato Valley are internally highly organized in multiepisodic relative microframes and inter-microframes (Fig. 7). An initial soft intermicroframe turns into microframe once it has been lithified, and the automicrite production continues around and within it.

In Guadiato, the 'fine-grained carbonate matrix' and cavities represent about $60-79 \%$ of the rock volume, whereas the automicrite production volume is higher than the external allomicrite input (which is less than $13 \%$ of the rock volume, on average). The mapping shows that the record of secondary automicrites is dominant (54\% of the rock volume, on average), whereas the primary automicrites average is around $16 \%$ of the rock volume.

The autochthonous internal sediment and the marine fibrous cement in the cavity system are, on average, 8 and $9 \%$ of the rock volume, respectively. Therefore, peloidal-dominated mud mounds from the Guadiato Valley are clearly dominated by automicrites (primary and secondary). The mud mounds are seen here as a continuous series of processes of automicrite production, allomicrite input, and internal reworking (chemical, physical, and/or biological processes).

\section{Primary automicrite distribution model}

The primary automicrites have a similar distribution (13$19 \%$ rock volume) throughout the different mega-structural mud mound stages (A-E in Fig. 2) in the Guadiato Valley. However, their growth morphologies (crusts, microcolumns, and microdomes) show a shallowing-upward trend.

A shallowing-upward mud mound phases model is defined herein (Fig. 8) combining (1) the total number and (2) presence of selected components per thin section. Calcareous algae and other components have been used as a light/ energy index on the basis of both mud mound and offmound facies analysis, which are characterized by distinctive biotic assemblages (Rodríguez-Martínez 2005), and following the previous works from the Béchar Basin, Algeria (Bourque et al. 1995; Madi et al. 1996).

Calcareous algae are accessory and minor components in these mud mounds (on average, $<1 \%$ and between 1 and 
Peloidal dominated mud mound

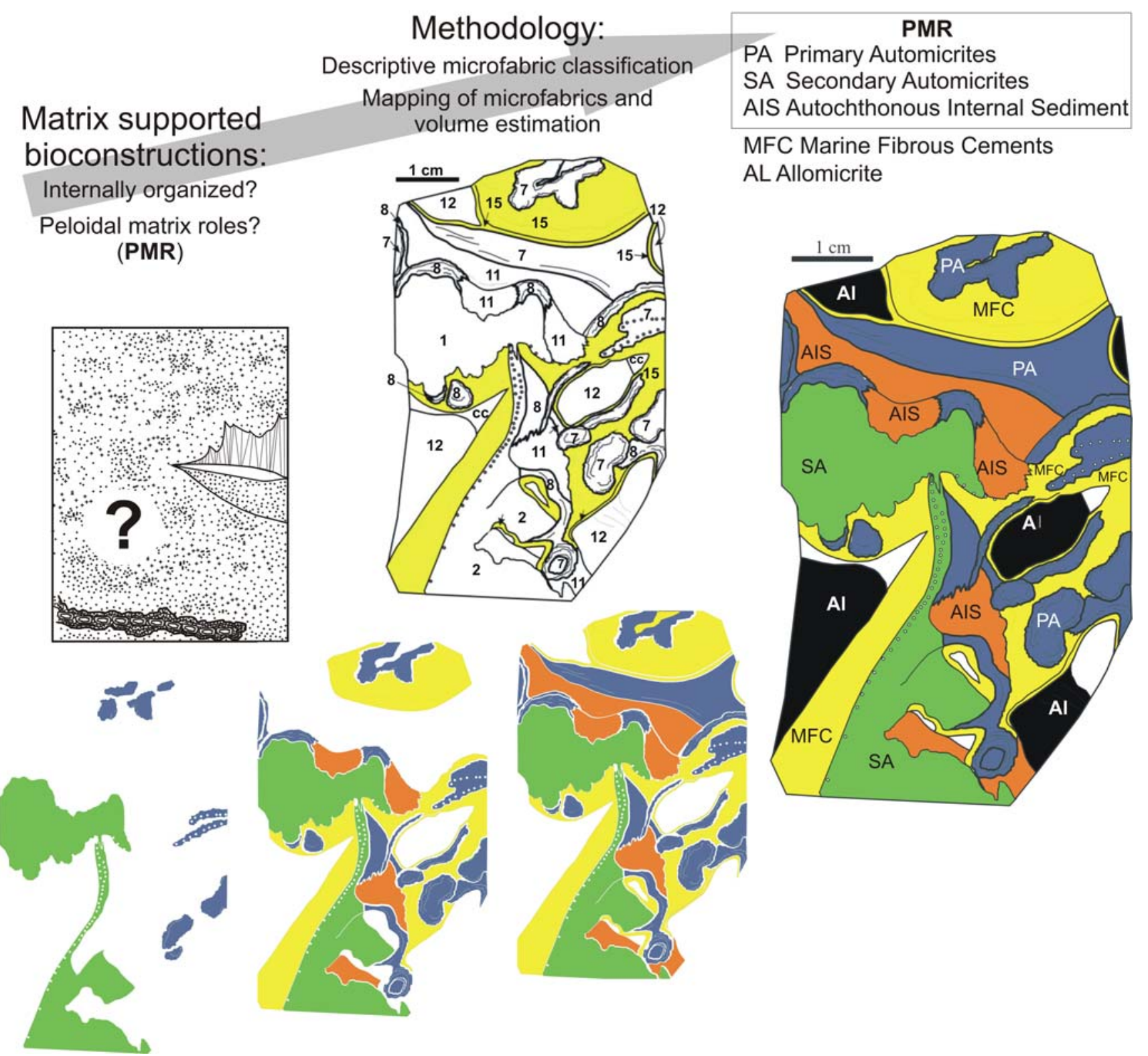

\section{Microframework}

MFC Marine Fibrous Cements

AL Allomicrite

Fig. 7 Methodology used in the reconstruction of the micro-framework from peloidal-dominated mud mounds. PMR Peloidal matrix roles

$3 \%$ of the rock volume, respectively) whereas they can appear in the off-mound facies as main and secondary components ( $>10 \%$ and between 5 and $10 \%$, respectively). In fact, the presence of different calcareous algae was taken as a good light/energy indicator, independent of the total number of algae, because trends are similar in both records of the mud mound and off-mound facies (Rodríguez-Martínez 2005).

The facies analysis of the coeval off-mound record shows the following features: (a) Fasciella has the most conspicuous distribution along the outer and inner platform, with a maximum abundance above the storm weather base; (b)

ungdarellaceans are much more restricted to intermound and flank areas, except for the upper part of the succession; (c) calcareous algae meadow deposits occur along the middle and inner platform as Fasciella, paleoberesellids, and Koninckopora-dominated belts from the deepest to shallow waters, respectively (Fig. 8a). Fasciella is generally accepted as red algae (Bourque et al. 1995; Madi et al. 1996; Gallagher 1998; Groves et al. 2003). The presence of paleoberesellids is common in shallow subtidal environments (Adams et al. 1992) at a depth of $10 \mathrm{~m}$ close to the fair weather base (Horbury and Adams 1996), and the cosmopolitan dasyclad Koninckopora is common in high-energy shallow-water 
A

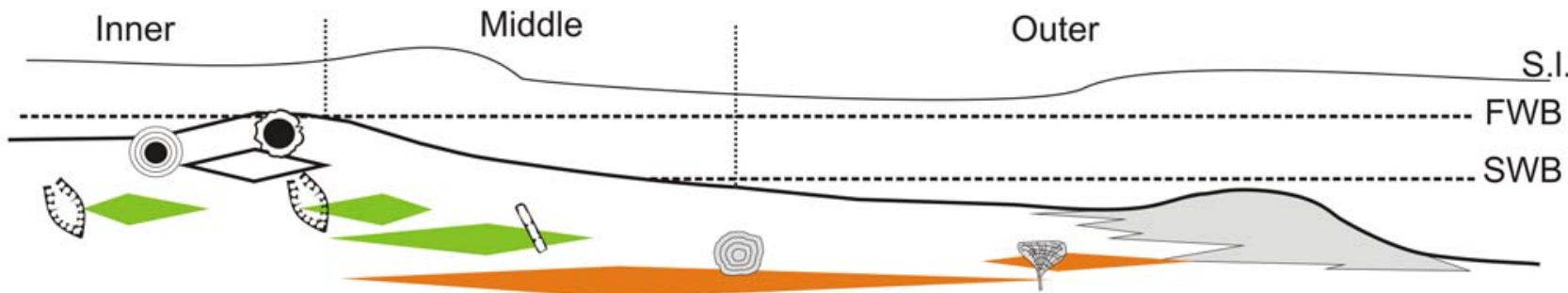

B Shallowing upwards model
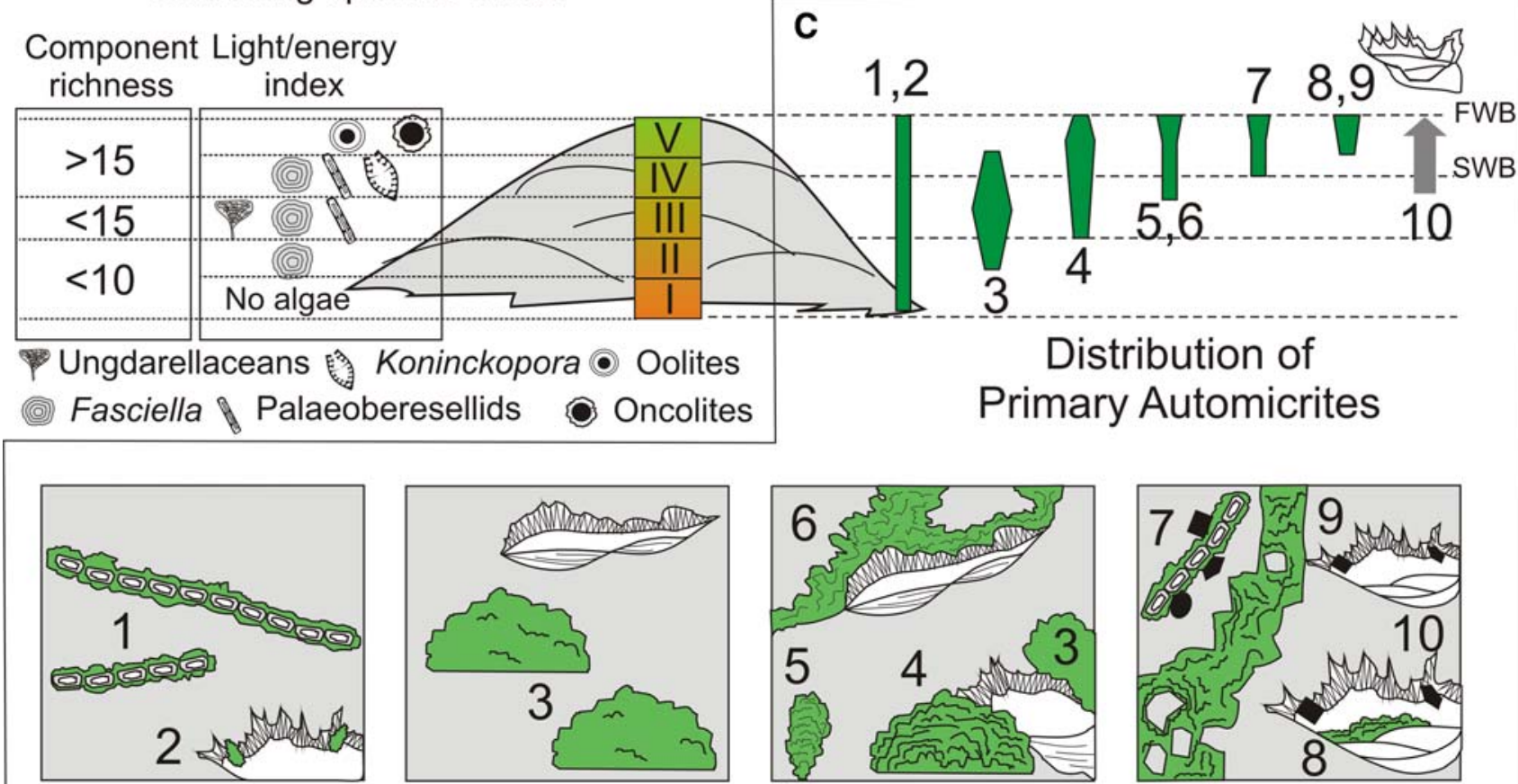

Growth morphologies of Primary Automicrites

Microencrusters

Fig. 8 a Distribution of some calcareous algae, oolites, and oncolites, as light/energy index indicators along the platform profile. b Shallowing-upwards mud mound model zones $(I-V)$ based on the component richness and the light/energy index: $I$ aphotic-disphotic zone; II disphotic zone; III disphotic to euphotic zone; IV true euphotic zone; $V$ euphotic and wave energy. c Distribution of the primary automicrites growth morphologies: 1,2 crusts around skeletal remains

deposits such as shoals (Mamet 1991). It forms true meadows (Wood 1940) close to and above the fair weather base, between a depth of 5-10 $\mathrm{m}$ (Gallagher 1998).

The autochthonous and parautochthonous record of calcareous algae and calcimicrobes in the mud mound is formed by Fasciella, Girvanella, ungdarellaceans, Aphralysia, and Renalcis. Moreover, the last two are quite uncommon (a presence of less than 10\% in samples with algae), and only Fasciella shows a higher frequency ( $>75 \%$ in samples with the presence of algae). Green algae, such as paleoberesellids and Koninckopora, are shallow-waterderived allochthonous remains in most of the mud mound mega-structural stages (Fig. 2). and cavity walls; 3 massive microdomes; 4 internally laminated microdomes; 5 microcolumns; 6 complex reticulate developments (bridge structures); 7 crusts intergrading with other microencrusters; 8 massive to internally laminated growths colonizing the cavity system; 9 colonizing secondary porosity associated with fractures and breccias. 10 Large reticulate cavities with complex fill sequences

Thus, the idealized shallowing-upwards mud mound sequence is formed by five phases, defined by the component richness and the light/energy component index (phases $\mathrm{I}-\mathrm{V}$ in Fig. 8b). Component richness is considered here as the total number of components per thin section. It has been grouped in low, middle, and high richness intervals: less than 10 , exactly 15 , and more than 15 components per thin section, respectively. Calcareous algae such as Fasciella, ungdarellaceans, Koninckopora, paleoberesellids, and other allochems (such as ooids and oncolites) have been chosen as a qualitative light/energy index.

Phase I is defined by very low component richness and the absence of calcareous algae. We interpret phase I as 
deep subtidal, aphotic to dysphotic conditions (Fig. 8b), whereas phase II is defined by the presence of Fasciella in low-richness assemblages. The presence of red algae together with the first occurrence of paleoberesellids and middle component richness, point to the dysphotic to euphotic transition and represent conditions close to the storm weather base (phase III in Fig. 8b). The arrival of the remains of the green algae Koninckopora, later followed by platform-derived grains such as oolites and oncolites, represents mud mound phases in true euphotic shallow-water conditions (phases IV and V, respectively, in Fig. 8b), between the storm and fair weather bases.

The observed frequency of primary automicrites is summarized in Fig. 8c. Crusts around skeletal remains and cavity walls occur without evidence of depth control, from the deepest to the shallow subtidal water mud mound phases $(\mathrm{I}-\mathrm{V})$. Massive microdomes are dominant in middle depth mud mound phases (III). The growth morphologies of primary automicrite begin to diversify toward shallow waters. The frequency of microdomes, especially the internally laminated ones, together with the microcolumns and more complex reticulated forms, increase during phases IV and V. Crusts with diverse microencrusters, growing into the remaining cavity system as well as into the secondary porosity, related to breccias and fractures, are common in shallow-water conditions where mud mounds grow close to the FWB. Under these conditions, the cavity system develops more reticulate shapes and is filled by complex sequences dominated by authochthonous internal sediment (homogeneous coarse peloidal microfabrics). Stromatactislike cavities are common from phases I-III, whereas reticulate cavities are dominant from phases IV-V.

\section{Summary and conclusions}

A spectacular succession with five mud mound mega-structural stages characterizes the Viseán bioconstruction record from the Guadiato Valley in the southwest region of Spain. These mud mounds have a 60-79\% volume average of a fine-grained carbonate matrix, mostly of peloidal character.

Thirteen mud mound microfabrics have been recognized on the following three factors: the composition of the main fraction (peloidal, intraclastic, bioclastic, and micritic fractions), distribution of sizes (homogeneous or heterogeneous), and type of 'support' (matrix- or cement-supported character).

The spectrum of microfabrics was analyzed and mapped directly over the thin sections. This methodology has allowed us to recognize the different roles of the peloidal matrix, and determine the best estimation of their volumetric importance and contribution to the mud mound microframework.
The internal organization of mud mounds from the Guadiato Valley shows a continuous series of automicrite production, allomicrite input, and internal reworking processes. The autochthonous production is much higher than the allochthonous input. In fact, these peloidal-dominated mud mounds have a high and complex multiepisodic microframework formed by primary and secondary automicrites (16 and $54 \%$ of the rock volume, on average) with the development of growth cavities filled by autochthonous internal sediment $(8 \%)$, allomicrites (13\%), and marine fibrous cements (9\%).

Primary automicrites are formed by homogeneous fine peloidal microfabrics (three subtypes) which display different growth morphologies (clusters, crusts, massive and laminated microdomes, microcolumns, and reticulate developments), as well as modes of occurrence (associated with skeletal components, microencrusters, cavities, and fractures). The distribution of the primary automicrite morphologies shows a shallowing-upwards pattern from the simplest (clusters and crusts) and most massive to the complex and internally laminated forms.

Secondary automicrites are formed by heterogeneous microfabrics (six subtypes belonging to the peloidal, intraclastic, and bioclastic-rich subclasses). They show a mixture of both in situ constructive and destructive, or reworking, processes. Thus, they are parautochthonous automicrites.

The autochthonous internal sedimentation or production of automicrites in the cavity system is formed by homogeneous coarse peloidal microfabrics (two subtypes).

Finally, the microfabrics dominated by the micritic fraction (two subtypes) represent the external allochthonous micrite input into the mud mound, and are considered allomicrites.

Acknowledgments This work was supported by the DGESICTBTE2000-1423 Spanish project and the Departamento de Estratigrafía from the Universidad Complutense de Madrid. This work was part of the $\mathrm{PhD}$ research project of Marta Rodríguez-Martínez. The authors also thank Wayne Ahr for his valuable comments about mud mounds over the years. The redrawing of hundreds of thin-section maps was finished in part due to the huge help from Concha Herrero, Ivan Moreno, and Rocio Giménez. We especially thank Markus Aretz and Andre Freiwald for their constructive critiques and suggestions.

\section{References}

Ábalos B, Díaz Cusí J (1995) Correlation between seismic anisotropy and major geological structures in SW Iberia: a case study on continental lithosphere deformation. Tectonics 14:1021-1040

Ábalos B, Carreras J, Druguet E, Escuder Viruete J, Gómez Puignaire M-T, Lorenzo Álvarez S, Quesada C, Rodríguez Fernández L-R, Gil-Ibarguchi J-I (2002) Variscan and pre-variscan tectonics. In: Gibbons W, Moreno T (eds) The geology of Spain. Geol Soc Lond, pp 155-183 
Adachi N, Ezaki Y, Liu J (2004) The fabrics and origins of peloids after the end-Permian extinction, Guizhou Province, South China. Sediment Geol 164:161-178

Adams AE, Horbury AD, Ramsay ATS (1992) Significance of palaeoberesellids (Chlorophyta) in Dinantian sedimentation, UK. Lethaia 25:375-382

Ahr WM, Stanton RJ Jr (1996) Constituent composition of early Mississippian carbonate buildups and their level-bottom equivalents, Sacramento Mountains, New Mexico. In: Strogen P, Somerville ID, Jones GLl (eds) Recent advances in the Lower Carboniferous geology, vol 107. Geol Soc Spec Publ Lond, pp 83-95

Aretz M, Chevallier E (2007) After the collapse of stromatoporid-coral reefs-the Famennian and Dinantian reefs of Belgium: much more than Waulsortian mounds. In: Álvaro JJ, Aretz M, Boulvain F, Munnecke A, Vachard D, Vennin E (eds) Paleozoic reefs and bioaccumulations: climatic and evolutionary controls, vol 275 . Geol Soc Spec Publ Lond, pp 163-188

Azor A, Expósito I, González Lodeiro F, Simancas JF, Martínez Poyatos D (2004) Propuesta de un modelo evolutivo para la Zona de Ossa-Morena. In: Vera JA (ed) Geología de España. SGE e IGME, Madrid, pp 188-189

Bermúdez-Rochas DD, Sarmiento GN, Rodríguez S (2004) Conodontos del Viseense superior (Carbonífero) de la Unidad de la Sierra del Castillo (Córdoba, España). Col Paleont 54:25-64

Bourque P-A, Gignac H (1983) Sponge-constructed stromatactis mud mounds, Silurian of Gaspé, Québec. J Sediment Petrol 53:521532

Bourque P-A, Madi A, Mamet BL (1995) Waulsortian-type bioherm development and response to sea-level fluctuations: upper Viséan of Becar basin, western Algeria. J Sediment Res B65:80-95

Bridges PH, Chapman AJ (1988) The anatomy of a deep water mudmound complex to the southwest of the Dinantian platform in Derbyshire, UK. Sedimentology 35:139-162

Bridges PH, Gutteridge P, Pickard NAH (1995) The environmental setting of Early carboniferous mud-mounds. In: Monty CLV, Bosence DWJ, Bridges PH, Pratt BR (eds) Carbonate mudmounds, their origin and evolution, vol 23. Inter Assoc Sediment Spec Publ, pp 171-190

Cabioch G, Camoin G, Webb GE, Le Cornec F, García Molina M, Pierre C, Joachimski MM (2006) Contribution of microbialites to the development of coral reefs during the last deglacial period: case study from Vanuatu (south-west Pacific). Sediment Geol 185:297-318

Camoin G, Gautret P, Montaggioni LF, Cabioch G (1999) Nature and environmental significance of microbialites in Quaternary reefs: the Tahiti paradox. Sediment Geol 126:271-304

Castanier S, Le Métayer-Levrel G, Perthuisot J-P (1999) Ca-carbonates precipitation and limestone genesis-the microbiogeologist point of view. Sediment Geol 126:9-23

Cavagna S, Clari P, Martire L (1999) The role of bacteria in the formation of cold seep carbonates: geological evidence from Monferrato (Tertiary, NW Italy). Sediment Geol 126:253-270

Chafetz HS (1986) Marine peloids: a product of bacterially induced precipitation of calcite. J Sediment Petrol 56:812-817

Cózar P (2003a) Foraminiferal taphofacies in the Mississippian rocks of the Guadiato area, SW Spain. Facies 49:1-18

Cózar P (2003b) Foraminiferal fauna and zonation from the Lower Carboniferous of the Guadiato area (SW Spain): comparison with European and North African foraminiferal zonal schemes and its paleobiogeographical implications. In: Ahr WM, Harris PM, Morgan WA, Somerville ID (eds) Permo-Carboniferous carbonate platforms and reefs, vol 78. SEPM Spec Publ, pp 162-177

Cózar P, Mamet BL (2001) Planohowchinia (Lasiodiscidae, Foraminiferida), a new late Viséan genus, southwestern Spain. J Foram Res 31:228-232
Cózar P, Rodríguez S (1999) Evolución sedimentaria del Carbonífero Inferior del área del Guadiato (España). Bol Geol Min 110:663-680

Cózar P, Rodríguez S (2003) The palaeoecological distribution of the endothyroids (Foraminifera) in the Guadiato area (SW Spain, Mississippian). Palaeogeogr Palaeoclimatol Palaeoecol 201:1-19

Cózar P, Rodríguez S (2004) Pendleian (early Serpukhovian) marine carbonates from SW Spain: sedimentology, biostratigraphy and depositional model. Geol J 39:25-47

Cózar P, Vachard D (2004a) A new Mississippian dasyclad alga (Chlorophyta) from SW Spain: implications for the reproductive evolution of the dasyclads during the Late Palaeozoic. Eclogae Geol Helv 97:175-181

Cózar P, Vachard D (2004b) Morphological adaptations of the late Mississippian problematic alga Calcifolium to fluctuating palaeoecologic environments. Lethaia 37:351-363

Défarge C, Gautret P, Reitner J, Trichet J (2009) Defining organominerals: comment on 'defining biominerals and organominerals: direct and indirect indicators of life' by Perry et al. (2007, Sedimentary Geology, 201, 157-179), Sediment Geol 213:152-155

Della Porta G, Kenter JAM, Bahamonde JR, Immenhauser A, Villa E (2003) Microbial boundstone dominated carbonate slope (Upper Carboniferous, N Spain): microfacies, lithofacies distribution and stratal geometry. Facies 49:175-208

Eguíluz L, Gil-Ibarguchi JL, Ábalos B, Apraiz A (2000) Superposed Hercynian and Cadomian orogenic cycles in the Ossa-Morena Zone and related areas of the Iberian Massif. Geol Soc Am Bull 112:1389-1413

Fagerstrom JA (1987) The evolution of reef communities. Wiley, New York

Flügel E (2004) Microfacies of carbonate rocks: analysis, interpretation and application. Springer, Berlin

Folk RL, Chafetz HS (2000) Bacterially induced microscale and nanoscale carbonate precipitates. In: Riding RE, Awramik SM (eds) Microbial sediments. Springer, Berlin Heidelberg New York, pp 40-49

Gabaldón V, Garrote A, Quesada C (1985) Geología del Carbonífero Inferior del Norte de la Zona de Ossa-Morena. Introducción a la excursión de la $5^{\mathrm{a}}$ reunión del grupo de Ossa Morena. Temas Geol Min 7:101-137

Gallagher SJ (1998) Controls on the distribution of calcareous foraminifera in the Lower Carboniferous of Ireland. Mar Micropaleontol 34:187-211

García-Mondéjar J, Fernández-Mendiola PA (1995) Albian carbonate mounds: comparative study in the context of sea-level variations (Soba, northern Spain). In: Monty CLV, Bosence DWJ, Bridges $\mathrm{PH}$, Pratt BR (eds) Carbonate mud-mounds, their origin and evolution, vol 23. Inter Assoc Sed Spec Publ, pp 359-384

Groves JR, Larghi C, Nicora A, Rettori R (2003) Mississippian (Lower Carboniferous) microfossils from the Chios Mélange (Chios Island, Greece). Geobios 36:379-386

Gürich G (1906) Les spongiostromides du Viséen de la Province de Namur. Mém Mus Roy Hist Nat Belgique 3:1-55

Horbury AD (1992) A Late Dinantian peloid cementstone-palaeoberesellid buildup from North Lancashire, England. Sediment Geol 79:117-137

Horbury AD, Adams AE (1996) Microfacies associations in Asbian carbonates: an example from the Urswick Limestone Formation of the southern Lake District, northern England. In: Strogen P, Somerville ID, Jones GLl (eds) Recent advances in the Lower Carboniferous geology, vol 107. Geol Soc Spec Publ Lond, pp 221-237

Hughes JA, Gooday AJ (2004) Associations between living benthic foraminifera and dead test of Syringammina fragilissima (Xenophyophorea) in the Darwin Mounds region (NE Atlantic). Deep-Sea Res I 51:1741-1758 
James NP, Ginsburg RN (1979) The seaward margin of Belize barrier and atoll reefs, vol 3. Inter Assoc Sedimentol Spec Publ, pp 1-191

Jeffery DL, Stanton RJ Jr (1996) Biotic gradients on a homoclinal ramp: the Alamogordo Member of the Lake Valley Formation, Lower Mississippian, New Mexico, USA. In: Strogen P, Somerville ID, Jones GLl (eds) Recent advances in Lower Carboniferous geology, vol 107. Geol Soc Spec Publ Lond, pp 111-126

Kazmierczak J, Coleman ML, Gruszczynski M, Kempe S (1996) Cyanobacterial key to the genesis of micritic and peloidal limestones in ancient seas. Acta Palaeontol Pol 41:319-338

Koch R, Senowbari-Daryan B, Strauss H (1994) The Late Jurassic 'Massenkalk Fazies' of southern Germany: calcareous sand piles rather than organic reefs. Facies 31:179-208

Lees A (1964) The structure and origin of the Waulsortian (Lower Carboniferous) "reefs" of west-central Eire. Philos Trans R Soc Lond B 247:483-531

Lees A, Miller J (1985) Facies variation in Waulsortian buildups. Part 2. Mid-Dinantian buildups from Europe and North America. Geol J 20:159-180

Lees A, Miller J (1995) Waulsortian banks. In: Monty CLV, Bosence DWJ, Bridges PH, Pratt BR (eds) Carbonate mud-mounds, their origin and evolution, vol 23. Inter Assoc Sedimentol Spec Publ, pp 191-271

Leinfelder RR, Krautter M, Laternser R, Nose M, Schmid DU, Schweigert G, Werner W, Keupp H, Brugger H, Herrmann R, Rehfeld-Kiefer U, Schoroeder JH, Reinhold C, Koch R, Zeiss A, Schweizer V, Christmann H, Menges G, Luterbacher H (1994) The origin of Jurassic reefs: current research developments and results. Facies 31:1-56

Macintyre IG (1985) Submarine cements-the peloidal question. In: Schneidermann N, Harris PM (eds) Carbonate cements, vol 36. SEPM Spec Publ, pp 109-116

Madi A, Bourque P-A, Mamet B (1996) Depth related ecological zonation of a carboniferous carbonate ramp: upper Viséan of Béchar basin, western Algeria. Facies 35:59-80

Mamet B (1991) Carboniferous calcareous algae. In: Riding R (ed) Calcareous algae and stromatolites. Springer, Berlin Heidelberg New York, pp 370-451

Mamet B, Martínez C (1981) Late Visean microfossils of the Las Caleras Bajas limestone (Córdoba, Spain). Rev Esp Micropal 13:105-118

Martínez Poyatos DJ (2002) Estructura del borde meridional de la Zona Centroibérica y su relación con el contacto entre las Zonas Centroibérica y de Ossa-Morena. Lab Xeol Laxe, serie Nova Terra 18. Edicions do Castro, 1-295

Martínez Poyatos D, Simancas JF, Azor A, González Lodeiro F (1998) Evolution of a piggyback basin in the southern Central Iberian Zone (Variscan Belt, SW Spain). Bull Soc Géol Fr 169:573-578

Matte P (1991) Accretionary history and crustal evolution of the Variscan belt in Western Europe. Tectonophysics 196:309-337

Monty CLV (1965) Recent algal stromatolites in the windward lagoon, Andros Island, Bahamas. Ann Soc Géol Belg 88:268-276

Mundy DJC (1994) Microbialite-sponge-bryozoan-coral framestones in Lower Carboniferous (Late Viséan) buildups of northern England (UK). In: Beauchamp B, Embry AF, Glass DJ (eds) Pangea: global environments and resources, vol 17. Can Soc Petrol Geol Memoir, pp 713-729

Neuweiler F (1993) Development of Albian microbialites and microbialite reefs at marginal platform areas of Vasco-Cantabrian basin (Soba reef area, Cantabria, N Spain). Facies 29:231-250

Nose M, Schmid DU, Leinfelder RR (2006) Significance of microbialites, calcimicrobes, and calcareous algae in reefal framework formation form the Silurian of Gotland, Sweden. Sediment Geol 192:243-265

Ortuño MG (1971) Middle Westphalian strata in south-west Spain. CR VI Con Int Carbon 3:1275-1293
Peckmann J, Campbell KA, Walliser OH, Reitner J (2007) A Late Devonian hydrocarbon-seep deposit dominated by dimerelloid brachiopods, Morocco. Palaios 22:114-122

Pérez-Estaún A, Bea F (eds) (2004) Macizo Ibérico. In: Vera JA (ed) Geología de España. SGE IGME, Madrid, pp 21-230

Pérez-Lorente F (1979) Geología de la Zona Ossa-Morena al Norte de Córdoba (Pozoblanco-Belmez-Villaviciosa de Córdoba), vol 281. Tesis Doctorales de la Universidad de Granada, pp 1-340

Pickard NAH (1996) Evidence for microbial influence on the development of the Lower Carboniferous buildups. In: Strogen P, Somerville ID, GL1 Jones (eds) Recent advances in the Lower Carboniferous geology, vol 107. Geol Soc Spec Publ Lond, pp $65-82$

Pomar L, Hallock P (2008) Carbonate factories: a conundrum in sedimentary geology. Earth Sci Rev 87:134-169

Pratt BR (1995) The origin, biota and evolution of deep-water mudmounds. In: Monty CLV Bosence DWJ, Bridges PH, Pratt BR (eds) Carbonate mud-mounds, their origin and evolution, vol 23. Inter Assoc Sedimentol Spec Publ, pp 49-123

Quesada C (1992) Evolución tectónica del Macizo Ibérico (una historia de crecimiento por acrecencia sucesiva de terrenos durante el Proterozoico superior y el Paleozoico). In: Gutiérrez-Marco JC, Saavedra J, Rábano I (eds) Paleozoico Inferior de Ibero-América. Universidad de Extramadura, Badajoz, pp 173-190

Reid RP (1987) Nonskeletal peloidal precipitates in upper Triassic reefs, Yukon Territory (Canada). J Sediment Petrol 57:893-900

Reitner J (1993) Modern cryptic microbialite/metazoan facies from Lizard Island (Great Barrier Reef, Australia), formation and concepts. Facies 29:3-40

Reitner J, Neuweiler FC (1995) Mud mounds: a polygenetic spectrum of fine-grained carbonate buildups. Facies 32:1-70 (coords)

Reitner J, Neuweiler F, Gautret P (1995) Part II. Modern and fossil automicrites: implications for mud mound genesis. Facies 32:4-17

Reitner J, Thiel V, Zankl H, Michaelis W, Wörheide G, Gautret P (2000) Organic and biochemical pattern in cryptic microbialites. In: Riding RE, Awramik SM (eds) Microbial sediments. Springer, Berlin Heidelberg New York, pp 149-160

Riding R (2000) Microbial carbonates: the geological record of calcified bacterial-algal mats and biofilms. Sedimentology 47:179-214

Rodríguez S, Hernando JM, Rodríguez-Curt L (2004) Estudio de los corales cyathópsidos (Rugosa) del Viseense superior de la Unidad de la Sierra del Castillo (Córdoba, España). Col Paleont 54:68-82

Rodríguez-Martínez M (2005) Las bioconstrucciones viseenses de tipo mud mound del área del Guadiato (Córdoba, SO de España). Tesis Doctoral de la Universidad Complutense de Madrid, 286 pp, 87 Apx., inédita

Rodríguez-Martínez M, Cózar P, Mas R, Rodríguez S (2003) Upper Viséan Saccamminopsis-sponge microbial mud mounds, Sierra de la Estrella, southwestern Spain. In: Ahr WM, Harris PM, Morgan WA, Somerville ID (eds) Permo-Carboniferous carbonate platforms and reefs, vol 78. SEPM Spec Publ, pp 189-200

San José MA, Herranz P, Pieren AP (2004) A review of the OssaMorena Zone and its limits. Implications for the definition of the Lusitan-Marianic Zone. J Iberian Geol 30:7-22

Schmid DU (1996) Marine Mikrobolithe und Mikroinkrustierer aus dem Oberjura. Profil 9:101-251

Shaphiro RS (2000) A comment on the systematic confusion of thrombolites. Palaios 15:166-169

Simancas JF, Pérez-Estaún A, (coords) Arenas R, Azor A, Ayarza P, Bastida F, Bea F, Carbonell R, Díaz García F, González Lodeiro F, Marcos A, Martínez Catalán JR, Martínez Poyatos D (2004) Evolución tectónica del Macizo Ibérico. In: Vera JA (ed) Geología de España, SGE IGME, Madrid, pp 224-230

Somerville ID (2003) Review of the Irish Lower Carboniferous (Mississippian) mud mounds: depositional setting, biota, facies, 
and evolution. In: Ahr WM, Harris PM, Morgan WA, Somerville ID (eds) Permo-Carboniferous carbonate platforms and reefs, vol 78. SEPM Spec Publ, pp 239-252

Somerville ID, Pickard NAH, Strogen P (1992) Early to mid-Viséan shallow water platform build-ups, north Co. Dublin, Ireland. Geol J 27:151-172

Sun SQ, Wright VP (1989) Peloidal fabrics in Upper Jurassic reefal limestones, Weald Basin, southern England. Sediment Geol 65:165-181

Tsien HH (1981) Ancient reefs and reef carbonates. Proceedings of 4th International Coral Symposium, Manila 1, pp 601-609

Webb GE (1994) Non-Waulsortian Mississippian bioherms: a comparative analysis. In: Embry AF, Beauchamp B, Glass, DJ (eds)
Pangea: global environments and resources, vol 17. Can Soc Petrol Geol Memoir, pp 701-712

Webb GE (1996) Was Phanerozoic reef history controlled by the distribution of nonenzimatically secreted reef carbonates (microbial carbonates and biologically induced cement)? Sedimentology 43:947-971

Webb GE (2002) Latest Devonian and Early Carboniferous reefs: depressed reef building after the middle Paleozoic collapse. In: Flügel E, Kiessling W, Golonka J (eds) Phanerozoic reef patterns, vol 72. SEPM Spec Publ, pp 239-269

Wood A (1940) Two new calcareous algae of the family Dasycladaceae from the Carboniferous limestone. Proc Geol Soc Liverpool 18:14-18 